\title{
Meningococcal disease
}

\author{
- a review based on a symposium held on 11 July 1992 at the Liverpool School of Tropical Medicine
}

\author{
Edited by C. A. HART and T. R. F. ROGERS*
}

Department of Medical Microbiology and Genito-Urinary Medicine, University of Liverpool, PO Box 147, Liverpool L69 3BX and "Department of Medical Microbiology, Westminster Hospital, Charing Cross and Westminster School of Medicine, 17 Horseferry Road, London SW1P 2AR

\section{Introduction}

Meningococcal disease is a worldwide problem. It occurs in epidemics across the so-called "meningitis belt" of sub-Saharan Africa every 7-10 years but recently epidemics of meningococcal disease have been reported from parts of Africa such as Tanzania and Malawi ${ }^{1}$ which are well outside this area. In addition, high or increasing levels of endemic meningococcal disease have been reported from Cuba, Brazil, parts of the UK and Norway. In contrast, in other regions of the world such as the Congo Basin, Zanzibar, Hong Kong and Djibouti, ${ }^{2}$ meningococcal disease is rare. We have little information on why epidemics occur or spread to other areas, why there are periodic rises in the incidence of sporadic meningococcal disease and why, in certain parts of the world, it is rare.

In the past decade we have begun to gain insights into the bacterial and host factors that are important in the development of meningococcal disease and its complications. Nevertheless, fulminant meningococcal septicaemia still presents a great problem of management and mortality rates of up to $30 \%$ are common.

This symposium brought together individuals with an interest in meningococcal disease across a wide spectrum of scientific and medical expertise, with the aim of providing an update on advances in understanding of the epidemiology, pathogenesis, management and prevention of meningococcal disease.

\section{Structure and epidemiological markers}

The meningococcus is one of the two major pathogenic species in the genus Neisseria. It is a relatively fragile and fastidious bacterium that has an affinity for certain mucous surfaces. Furthermore, it is able to enter the bloodstream to produce potentially lifethreatening disease. ${ }^{3}$

Structurally, the meningococcus resembles other gram-negative bacteria (fig. 1). It has two cell membranes, one on each side of the rigid peptidoglycan layer. Approximately $50 \%$ of the outer leaflet of the outer membrane is composed of amphiphilic lipooligosaccharide (LOS) molecules. The hydrophobic portion of the molecule is lipid A which is the active moiety of endotoxin. The structure of the hydrophilic oligosaccharide portion is variable and provides a basis for epidemiological typing (table I). The outer membrane of the meningococcus continually produces blebs which are released as vesicles rich in endotoxin (fig. 2). On the outside of the outer membrane is a capsule composed of acidic polysaccharide. This is (except for group-B strains) highly antigenic and forms the basis for the major epidemiological subdivision of meningococci, namely serogrouping (table I). Meningococci can be typed and subtyped on the basis of epitopes on class 2 or 3 , and class 1 outer-membrane proteins (OMPs), respectively. ${ }^{4}$ These proteins are integral membrane proteins and act as porins transporting molecules in and out of the bacterial cell. These groups, types, subtypes and LOS immunotypes can vary independently and form a sensitive method for discriminating between meningococci, particularly those of group B and group C. Thus, for example, a meningococcus could be group B, type 15 , subtype P14, immunotype LS-8 (B15, P1-4, LS-8). In addition, virulent meningococci express filamentous projections called pili (fig. 2). These enable meningococci to attach to mucosal epithelial cells and to endothelial cells, e.g. in the central nervous system. ${ }^{5}$ Pili may be one of two types, class I or class II, ${ }^{6}$ although this has not yet been widely used for epidemiological purposes.

For further discrimination between group B meningococci, assessment of restriction fragment length polymorphisms has proved useful. ${ }^{7}$ Another typing scheme for meningococci based on iso-enzymes called multilocus enzyme electrophoresis has been developed. ${ }^{8,9}$ This is based on the presence of iso-forms of cytosolic enzymes whose mol. wts vary between different strains of meningococci. It is a very powerful tool and has, for example, enabled the movement of a particular clone of group-A meningococci (clone III-1) to be tracked from China to Nepal in 1983, to India 


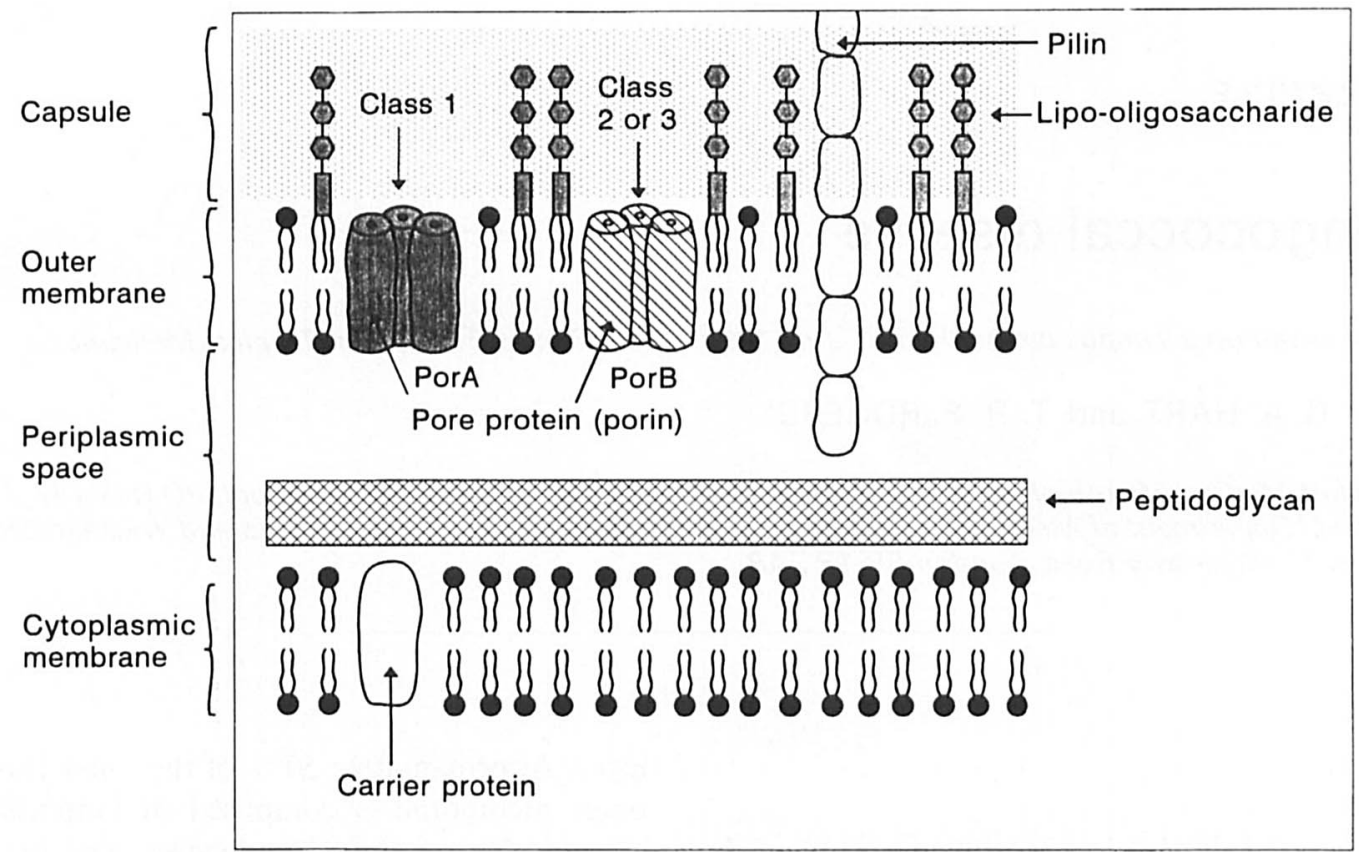

Fig. 1. A diagram of the structure of the meningococcal cell wall indicating structures used in epidemiological typing.

Table I. Epidemiological subdivisions of meningococci

\begin{tabular}{|c|c|c|}
\hline Subdivision & Variable & Nomenclature \\
\hline Group & $\begin{array}{l}\text { Acidic capsular } \\
\text { polysaccharides }\end{array}$ & $\begin{array}{l}\text { A, B, C, D, 29E, } \\
\text { H, I, K, L, } \\
\text { W135, X, Y, Z }\end{array}$ \\
\hline Type & $\begin{array}{l}\text { Class } 2 \text { and } 3 \text { outer- } \\
\text { membrane proteins }\end{array}$ & $1-20$ (for group B) \\
\hline Subtype & $\begin{array}{l}\text { Class } 1 \text { outer-membrane } \\
\text { proteins }\end{array}$ & 1-7 (for group b) \\
\hline Immunotype & Lipo-oligosaccharide & 1-8 (for group B) \\
\hline $\begin{array}{l}\text { Multilocus } \\
\text { enzyme } \\
\text { electrophoretic } \\
\text { types }\end{array}$ & Cytoplasmic iso-enzymes & Many \\
\hline
\end{tabular}

and Pakistan in 1985, to Mecca in 1987 and thence to the meningitis belt in $1989 .{ }^{9}$

In England and Wales, the majority (69\%) of cases of infection are due to group-B meningococci followed by $28 \%$ due to group-C meningococci. ${ }^{10}$ At present there is a hyperendemic phase of meningococcal disease in the UK and the highest rates are in the north and west of England (e.g., Mersey region 4.7 cases/ 100000 population, North West region 3.5/100000). ${ }^{10}$ A complex of related electropherotypes (ET-5) of group-B meningococci have been associated with hyperendemic disease throughout the world. ${ }^{8}$ In England and Wales these are present as sulphonamideresistant strains of group B15 P1.16 and B4 P1.15 which, apparently, are more likely to infect older children and adolescents than the sulphonamidesensitive strains. ${ }^{10}$ The commonest phenotypes isolated in England and Wales were B15 P1.16 (18\%), Bnt P1.15 (13\%) and B2b P1.10 (13\%). Amongst group-C strains, C2a (34\%) and C2b (39\%) were the major phenotypes in $1991 .^{10}$
It is clear that the development of precise methods of grouping, typing, subtyping and electropherotyping meningococci has provided powerful tools for monitoring the spread of particular strains of meningococci both within communities and throughout the world.

\section{Clonal AND VARIABLE PROPERTIES OF NEISSERIA MENINGITIDIS}

M. Achtman

Max-Planck-Institut für molekulare Genetik, D-1000 Berlin 73, Germany

Serogroup-A meningococci from diverse epidemics since the 1960 s have been subjected to multi-locus enzyme electrophoresis (MLEE) in various laboratories. ${ }^{11-14}$ Electrophoretic types (ETs) were grouped in fairly stable "clones", which themselves were associated in the larger so-called "subgroups". ${ }^{11}$ In a recent analysis in which results obtained with reference strains from these diverse sources were integrated, elucidated 84 ETs which fell into nine subgroups designated I-III, IV-1 and IV-2 and V-VIII (fig. 3), but could not confirm the prior assignments to "clones". ${ }^{5}$ The bacteria were also tested for expression of the conserved pilin epitopes called class I, class IIa and class IIb, and for expression of serosubtyping epitopes associated with the VR1 and VR2 variable regions of the class 1 protein. ${ }^{15}$ Bacteria within each subgroup were fairly homogeneous for both sets of antigens (fig. 3) and for expression of variable epitopes on IgAl protease. ${ }^{16}$ Thus, most of the different ETs can best be regarded as representing the occurrence of minor and rare variation due to mutation and horizontal genetic exchange. The results also show that sero-subtyping monoclonal antibodies (MAbs) were not available for both VR1 and VR2 of 


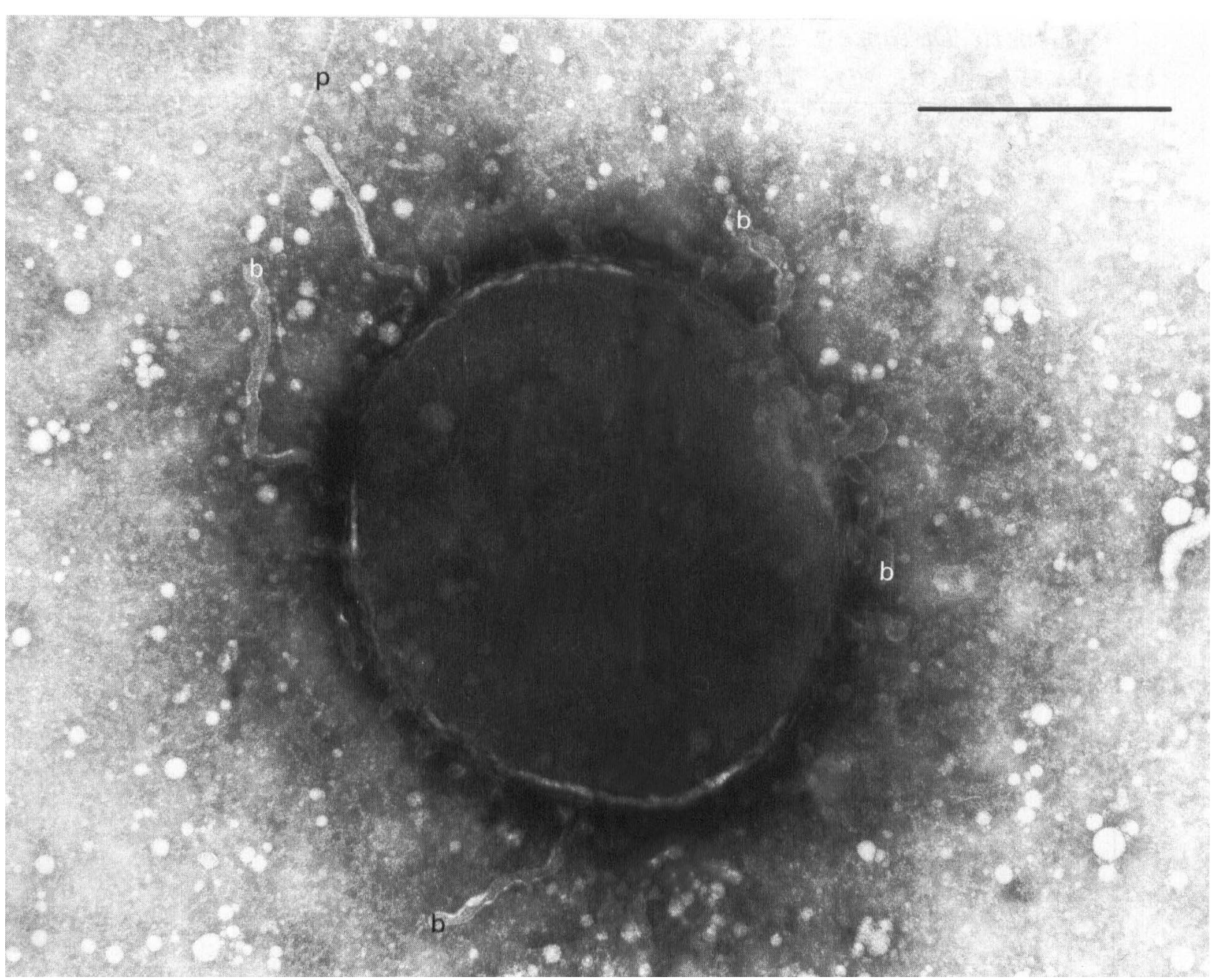

Fig. 2. An electromicrograph of a negatively-stained meningococcus showing pili (p) and blebbing from the outer membrane (b) (bar, $0.5 \mu \mathrm{m})$.

numerous serogroup-A meningococci. The VR regions which did not react contain unique sequences, ${ }^{17}$ indicating the need for additional sero-subtyping MAbs.

Almost all isolates from any one epidemic, epidemic wave or pandemic of serogroup-A disease belonged to a common subgroup and most bacteria from any one subgroup belonged to a single ET (fig. 3). More detailed analyses have been performed with serogroupA meningococci isolated during (1982-1983) and after (1983-1988) an epidemic in The Gambia. ${ }^{18}$ Essentially all these bacteria belonged to a single ET of subgroup IV-1, and were uniform not only for the subgroup properties described above but also for expression of the L9 LOS immunotype and in the amount of capsular polysaccharide synthesised. After the epidemic, rare strains were isolated with altered LOS, or that did not express the class 1 protein or synthesised increased amounts of capsular polysaccharide or with any combination of these characters; three of these strains have proved impossible to kill by antibodymediated complement activation. ${ }^{18}$

All serogroup-A meningococci tested from epidemics in West Africa in the early 1980s were also subgroup IV-1 ${ }^{11}$ as were most serogroup-A meningococci isolated there from endemic disease since the early 1960s and a minor proportion of epidemic isolates in the 1960s and 1970s. ${ }^{11,19}$ Subgroup IV-1 strains have not been isolated outside West Africa, except in India. ${ }^{15,20} \mathrm{~A}$ total of eight class 5 proteins, called $5 \mathrm{a}-5 \mathrm{~h}$, have been distinguished in different isolates of this subgroup. ${ }^{21,22}$ Class 5 proteins are trimeric, heat-modifiable and highly basic OMPs which are variable in expression and correspond to the P.II opacity proteins in $N$. gonorrhoeae. ${ }^{23}$ The class 5 proteins from subgroup IV-1 have been subdivided into seven Opa proteins encoded by opa genes, which are recognised by $\mathrm{MAb} 4 \mathrm{~B} 12 / \mathrm{C1}^{21}$ and the Opc protein (formerly called $5 \mathrm{c}$ ) recognised by $\mathrm{MAb}$ A222. ${ }^{24}$ The protein sequences and regulatory mechanisms differ markedly between Opa and Opc proteins $;{ }^{24}$ the Opa proteins expressed by meningococci can vary with the subgroup and even with the locale where the bacteria were isolated ${ }^{22}$ while the Opc protein is expressed by unrelated meningococci of diverse serogroups. ${ }^{21}$ With rare exceptions, only three Opa proteins or Opc, or both an Opa and Opc proteins, were variably expressed by bacteria from The Gambia. ${ }^{25}$ Sequence analyses have shown that Gambian subgroup IV-1 isolates possess only three opa genes (Hobbs, Cannon and Achtman, unpublished data) whereas a strain of ET-37 complex serogroup-C 


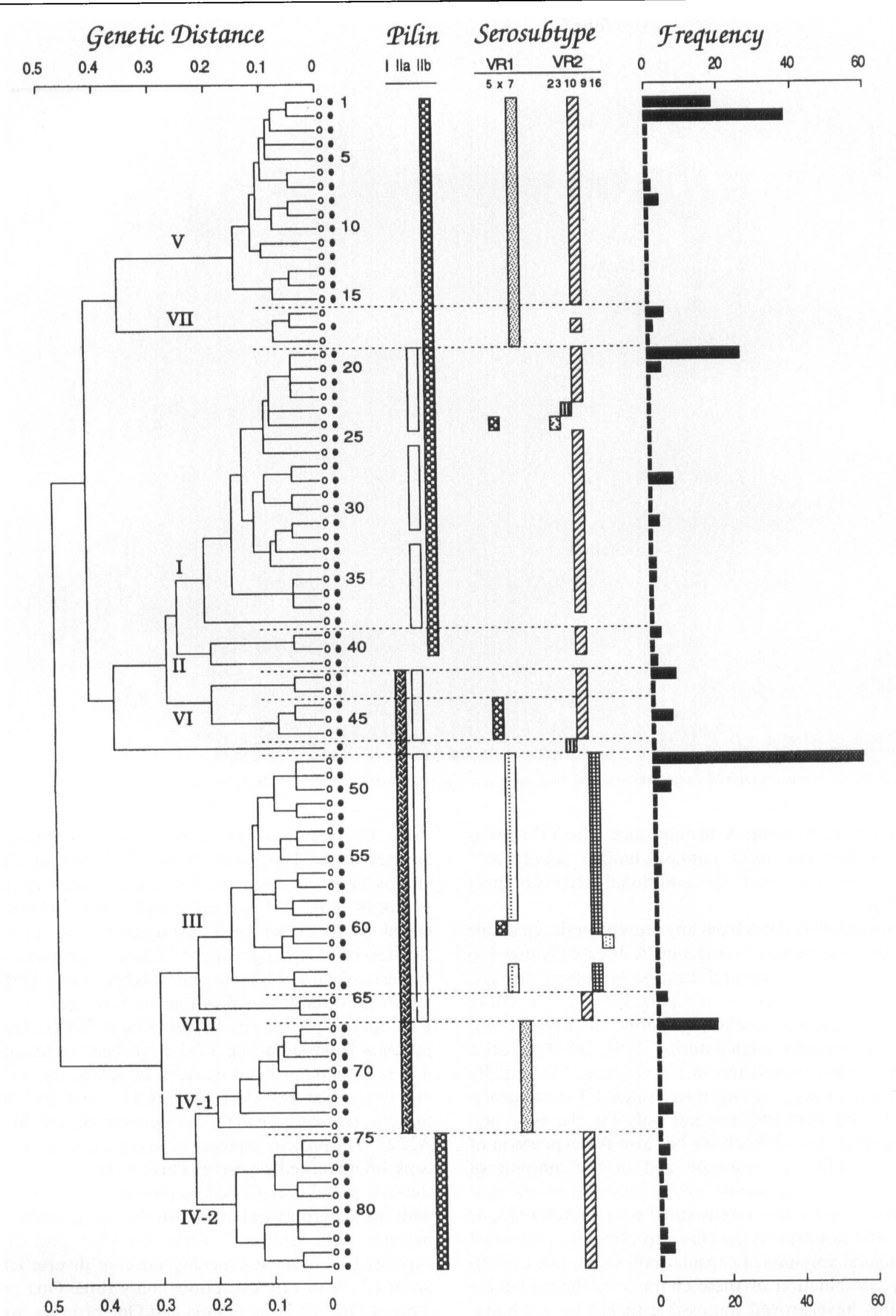

Fig. 3. Genetic relationships and antigenic patterns of $84 \mathrm{ETs}$ of meningococci ${ }^{15}$ Genetic distance: the dendrogram resulting from cluster analysis shows the genetic distance at which the clusters divided. The ET numbers are indicated at the end of the braces as is the serotype $(O$, serotype $4 ; 0$, serotype 21 ). The subgroup designations are indicated at the branching points (I, II, etc). The horizontal dotted lines are aligned with serological changes in the rest of the figure. Pilin: reactivity with MAbs defining different pilin epitopes is indicated by rectangles. Serosubtype: reactivity with MAbs to the individual serosubtypes is indicated by rectangles. Frequency: number of strains tested of each ET. 
meningococci (see below) possesses four ${ }^{26}$ The seven Opa proteins expressed by subgroup IV-1 bacteria represent the results of horizontal genetic exchanges which have resulted in recombinational replacement of variable regions within individual opa genes (Hobbs, Cannon and Achtman, unpublished data). In contrast, no variation in the DNA sequence of the opc gene has yet been detected although some strains, such as those of the ET-37 complex, totally lack the gene. ${ }^{27}$

Serogroup-A, subgroup-III meningococci have caused two pandemic waves which have originated in the Far East and have swept across the world. ${ }^{22}$ These strains caused an epidemic in Mecca, Saudi Arabia in $1987^{12}$ from where they spread to cause epidemics which are still continuing in East Africa. Subgroup-III meningococci from both pandemic waves variably expressed Opc and the Opa proteins designated 5a, 5f, $5 \mathrm{~h}$ and $5 \mathrm{i}$. Proteins 5a, 5f and 5h were indistinguishable from the proteins with the same designation in subgroup IV-1 although we know of no direct contact between the bacterial groups between the early 1960 s and the late 1980s.

The general function of class 5 proteins is not known but recent data may have elucidated part of the role of Opc in pathogenesis. Meningococci which express diminished amounts of capsular polysaccharide can adhere to and invade human endothelial and epithelial cells if they express large amounts of Opc. ${ }^{28}$ Binding is inhibited by MAbs to Opc. Opc was a component of the OMP complex vaccine used to immunise 100000 Norwegian adolescents and most reacted strongly, producing bactericidal antibodies to $\mathrm{Opc}{ }^{29} \mathrm{Opc}$ also seems to have been a component of the Cuban VAMengo-BC vaccine because many hybridomas generated from peripheral blood lymphocytes from immunised Cubans were specific for that protein. ${ }^{30}$ Opc is also highly immunogenic during nasopharyngeal carriage and disease. ${ }^{29}$ Only meningococci expressing large amounts of Opc are sensitive to bactericidal killing and only those variants are capable of adhesion and invasion. In The Gambia, meningococci isolated from the nasopharynx expressed large amounts of Opc more often than did bacteria isolated from the bloodstream or cerebrospinal fluid. ${ }^{25}$ I propose that expression of Opc is needed for adhesion and passage through cells but that the bacteria evade protection immunity because, at any one time, a large proportion of the population expresses low amounts of Opc or none. It remains unclear why adhesion and invasion can be observed in the laboratory only with bacteria that express diminished amounts of capsular polysaccharide.

It may be instructive to compare the observations summarised above with those obtained for serogroupC bacteria of the ET-37 complex. Between 1989 and 1991, most bacteria isolated from endemic disease in Mali, West Africa, were serogroup C, serotype 2a, serosubtype $\mathrm{P} 1.2, \mathrm{y}$ and expressed class IIb pili. ${ }^{31}$ These bacteria belong to the ET-37 complex ${ }^{32}$ which has caused outbreaks in South and North America as well as being a common cause of endemic disease in Europe. The meningococci responsible for outbreaks in US army recruits which led to the development of the $\mathrm{A}+\mathrm{C}$ polysaccharide vaccine ${ }^{33}$ were of the ET-37 complex. ${ }^{32}$ Unlike the constancy described above for serogroup-A bacteria, the ET-37 complex is antigenically diverse. Serogroups B, C, Y and W-135, serotypes $2 \mathrm{a}$ and $2 \mathrm{~b}$ and serosubtypes $\mathrm{P} 1.2,5$ and $\mathrm{P} 1.2,5$ have all been associated with the ET-37 complex, although most isolates have been $C: 2 a: P 1.2,5$ and have expressed class IIb pilin. Whereas any one strain possesses only four opa genes (and no opc gene), $26 \mathrm{Opa}$ protein variants which differed serologically or upon migration on SDS-PAGE were distinguished within the ET-37 complex. ${ }^{32}$ Within certain locales, such as the endemic isolates from Mali, the bacteria were homogeneous but it seemed that this was rather exceptional and variability was more common.

Taken together, these analyses indicate that certain genetically related bacteria have been responsible for most of the outbreaks and cases of meningococcal disease on a global basis. The stability of antigenic properties varies with the group of organisms and these groups can currently only be identified reliably by MLEE. Recombinational events can lead to changes within the bacterial genome which are most readily observed by comparisons of genetically related bacteria from diverse locales. The currently available serological tests are inadequate to recognise these bacterial groupings and will indicate variation when global analyses are performed.

Pilation in NEISSERIa MENINGITIDIS AND ITS CONSEQUENCES

J. R. Saunders, J. Wakeman, G. Sims, H. O'Sullivan, C. A. Hart* and M. Virji $\dagger$

Department of Genetics and Microbiology, *Department of Medical Microbiology, University of Liverpool, PO Box 147, Liverpool L69 3BX, and †Department of Paediatrics, University of Oxford

The surface of $N$. meningitidis is composed of various biologically active molecules, many of which are highly variable, most notably, OMP II (opacity

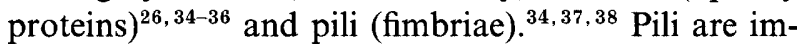
portant adhesins in meningococci and isolates from patients are almost invariably pilate when observed microscopically. Pilation appears to be required for colonisation of host mucosal surfaces and for at least some stages of invasive disease caused by these bacteria..$^{379-43}$ Pili are filamentous protein appendages which extend considerable distances from the bacterial surface and are probably responsible for initial interaction with host epithelial cells and subsequently with endothelial cells. ${ }^{5,42-44}$

Pili produced by pathogenic Neisseria spp. are composed of repeated subunits of pilin polypeptide with approximately 10000 pilin subunits assembled to form an individual pilus. ${ }^{23,45}$ Meningococci have been observed to produce either one of two types of pilus, class I and class II (table II). ${ }^{5,6,44,46-52}$ Class I pili are 
Table II. Similarities and differences in class I and II meningococcal pili

\begin{tabular}{|c|c|c|}
\hline Character & Class I & Class II \\
\hline Reaction with MAb SM1 & + & - \\
\hline Reaction with MAb SM2 & + & - \\
\hline $\begin{array}{l}\text { Subunit mol. wt of pilin } \\
\text { (kDa) }\end{array}$ & $16-23$ & $13-18$ \\
\hline $\begin{array}{l}\text { Homology with gonococcal } \\
\text { pilE gene in producing cell }\end{array}$ & + & + \\
\hline $\begin{array}{l}\text { Homology with PS1 (SM1 } \\
\text { epitope) oligonucleotide } \\
\text { probe }\end{array}$ & + & $\begin{array}{l}\text { Varies with } \\
\text { strain }\end{array}$ \\
\hline $\begin{array}{l}\text { Required for adhesion to } \\
\text { epithelial and endothelial } \\
\text { cells }\end{array}$ & + & + \\
\hline $\begin{array}{l}\text { Antigenic and functional } \\
\text { variation }\end{array}$ & + & + \\
\hline $\begin{array}{l}\text { Adherence to HEp-2 } \\
\text { epithelial cells }\end{array}$ & + & - \\
\hline $\begin{array}{l}\text { Adherence to Chang } \\
\text { epithelial cells }\end{array}$ & + & + \\
\hline Mean diameter $(\mathrm{nm})(\mathrm{SD})$ & $5.95(0.80)$ & $8.47(0.88)$ \\
\hline
\end{tabular}

similar in almost all aspects to the pili produced by all strains of $N$. gonorrhoeae; both react with MAbs SM1 and SM2. In contrast, class II meningococcal pili do not react with these antibodies. However, some epitopes may be shared by the two classes of pili. ${ }^{37,51-53}$ The gonococcal and meningococcal class I pilin molecule can be divided into three regions..$^{48,54-56}$ The $53 \mathrm{~N}$-terminal amino acids of mature pilin are conserved between antigenically distinct molecules constituting the conserved $(\mathrm{C})$ region. The central portion lying between amino acid 54 and the first cysteine residue (Cys 1) at $c$. residue 120 , constitutes the semivariable (SV) region. Within SV, there are five short peptide regions that are conserved, but intervening areas are subject to numerous amino-acid substitutions when different pilin variants are compared. The carboxyl-terminal end, from Cys 1 at residue -120 to the $\mathrm{C}$-terminus at $c$. residue 160 , is known as the hyper-variable (HV) region and contains numerous substitutions deletions and insertions of amino-acid sequence, when variant pili are compared. The sequence between the two cysteine residues has been shown to elicit the dominant antigenic response in man and animals. ${ }^{57-59}$ Antibodies produced by patients infected by gonococci show limited cross-reactivity with different pili produced by a single strain. ${ }^{60}$ MAbs SM1 and SM2 react with all gonococcal pili and a high proportion of the meningococcal pili so far studied. $^{46,47,50,52}$ A slight majority of meningococcal isolates (c. $60 \%$ ) express pili that react with MAb SM1 (and SM2) and which have been termed class I. About $40 \%$ of isolates produce class II pili that do not react with MAbs SM1 and SM2. The SM1 isotope has been localised to a pentapeptide that spans residues 49-53 at the distal end of the $\mathrm{C}$ domain of pilin ${ }^{61}$ Chromosomes of strains producing class II pili are apparently unable to elicit class I pili but contain silent truncated pilin genes that are homologous to class I and gonococcal pilin sequences. This suggests that the ability to express class I pili has been lost during evolution and may have been replaced by class II pilinencoding genes. ${ }^{46}$ Class I and class II pili are equally adherent to human endothelial cells, suggesting that, although the two classes of pili are genetically and structurally different, they have functional similarities. ${ }^{44}$ Class II pilate bacteria have reduced adhesion to HEp-2 cells compared with bacteria producing class I pili, indicating that there are tissue tropism differences between class I and class II pili. ${ }^{5}$ Variation in the antigenic nature of class I meningococcal pili in strain MC58 seems to affect adherence to epithelial cells but not to endothelial cells. Thus, although pilus-facilitated adherence is presumably mediated through receptors on human epithelial cells, there must be quantitative or qualitative differences, or both, in the distribution of receptors for both classes of pili on epithelial cells from different tissues. Class II pili can be divided into two subclasses based on their reaction with different MAbs and a MAb that reacts with the majority of class II meningococcal pili also reacts with the pili of $N$. lactamica (M. Achtman, personal communication). Therefore, class II meningococcal pili could have a common genetic ancestry with those of $N$. lactamica. It is conceivable that interspecies gene transfer (most probably by transformation) may have permitted $N$. meningitidis to acquire pilin genes from commensal neisseriae to replace those lost as a consequence of the natural instability of the class I pilE locus.

Genes that code for pilin have been located and characterised in both $N$. gonorrhoeae and class I pilusproducing $N$. meningitidis. ${ }^{46,48,56,62,63}$ An intact pilin gene and promoter are found only at the expression site pilE which is present as a single copy in the genomes of meningococci. Other silent loci (pilS), contain variant pilin sequences, truncated at the $5^{\prime}$ end and lacking a promoter. ${ }^{64,65}$ Two genes, pilA and pilB, involved in the regulation of expression of pilin have been located downstream of the gonococcal pil $\mathrm{E}^{66,67}$ and presumably there are analogues in meningococci. PilB probably spans the outer membrane and acts as a sensor to environmental conditions, whereas PilA behaves as a response regulator and has been implicated in pilus biogenesis. A further pilin-associated locus called pilC encodes the $110-\mathrm{kDa}$ PilC protein which has been implicated also in pilus biogenesis and, since this polypeptide co-purifies with pilin, may play a role in adhesion per se.

Expression of neisserial pili can be spontaneously turned on and off in a phase variation and a single cell can produce offspring that express structurally, antigenically and functionally distinct pilins through the process of antigenic variation. Both types of change arise as the consequence of alterations in expression at pilE, or an alteration in the relative influence of pilin accessory genes, or both. The actual mechanisms by which these changes take place remain to be resolved. Phase variation may be either reversible or nonreversible. A P-n ( 
results from deletions in the $5^{\prime}$ region of pilE that remove its promoter ${ }^{68-70}$ As each neisserial cell usually contains only one copy of the pilE promoter, loss is permanent, as is the ability to produce pili. ${ }^{71}$ P-rp(Pili-, revertible, pilin-) derivatives produce a pilin mRNA with a mutation that codes for a truncated or abnormal pilin protein whereas P-rp $+(\underline{\text { Pili-, }}$ revertible, pilin + ) cells can produce a full pilin polypeptide, containing a missense mutation in a region encoding a domain vital for pilus assembly. Reversion of these two phenotypes to $\mathrm{P}+$ can be achieved by one of the pil Sequences recombining with the expression site in a gene conversion event. Different types of phase variation occur leading to the production of the "abnormal" pilin polypeptides; S-pilin is pilin polypeptide that has been abnormally processed at the prepilin stage, is secreted to the outside of the cell and cannot be assembled in the outer membrane; L-pilin results from a partial duplication of the pil gene at the expression locus. ${ }^{72,73}$

Neisseriae can exploit their ability to produce a nonpilate, non-attaching phase to desorb from initial sites of infection and allow movement to other locations. The non-pilate state may also enable the organisms to be transmitted from one host to another; reverting to the pilate form would then be advantageous once a new infection site has been reached. Pilus antigenic variation is due to the appearance of a new nucleotide sequence at the pilE locus, resulting in the production of an assembled pilus with a novel subunit pilin aminoacid sequence. Variant pili may help the organism to colonise different tissues during the course of an infection and avoid the immune system of the host by presenting a succession of different antigenic stimuli.

The transfer of sequences from pilS to pilE may occur by reciprocal, homologous recombination ${ }^{74}$ or, more frequently, by non-reciprocal homologous recombination (gene conversion). ${ }^{65,69}$ In gene conversion, the donating pilS sequence replaces the $3^{\prime}$ portion of the pilE gene, which is subsequently lost from the genome with a stored copy of the donated pils gene remaining. Novel pil sequences may be spliced into pilE by the process of deletion repair where deletions arising spontaneously by illegitimate recombination are repaired by using the pilS genes as a template. ${ }^{75}$ Donated pil S gene segments could be acquired by transformation from autolysed neisserial cells. ${ }^{74,76}$ In contrast, some workers argue that transformation has no effect on pilus variation but may be involved in the spread of beneficial pil gene sequences throughout an infecting population. ${ }^{77}$ It has also been suggested that transformation may act as a trigger for pilin gene reassortment. ${ }^{78}$ The variable nucleotide domains within a pilS sequence may act as "mini-cassettes" in pilus antigenic variation, recombining with the corresponding segment of $p i l \mathrm{E}$ to produce variant pilin molecules. ${ }^{65}$ Short portions of the pilE gene would be replaced in the generation of a novel pilin coding sequence, rather than the whole $3^{\prime}$ end of the gene. This notion is also crucial to the deletion-repair theory of antigenic variation, in which short tracts of the pilE site flanked by short directly repeated sequences would be deleted and subsequently repaired by using the appropriate part of a pilS segment as a template. ${ }^{75}$

Summary. Pili present a highly variable adhesin to the surface of $N$. meningitidis. The ability of these bacteria to switch reversibly between a pilate and nonpilate state is crucial in allowing the pathogen to absorb to and desorb from epithelial and endothelial cells. Meningococci can produce one or other of two kinds of pili, class I and class II, both of which promote binding of these bacteria to epithelial and endothelial cells. Class I and class II pili seem to possess different specificities for adhesion to different types of epithelial cell. Furthermore, it appears that the primary amino-acid sequence of the pilin molecule can influence the adhesion specificity of mature pili. The underlying mechanisms for generating pilus diversity at the DNA level confer a great degree of plasticity in the structural gene (pilE) for the pilin subunit of class I pilin.

This work was supported by grants from the National Meningitis Trust and by postgraduate studentships to G.S. from the Science and Engineering Research Council and to H.O'S. from the Medical Research Council.

\section{HOST RESPONSES TO MENINGOCOCCAL INFECTIONS}

\section{R. A. Wall}

Department of Microbiology, Northwick Park Hospital, Middlesex $H A 13 U J$

Strains of $N$. meningitidis are genetically diverse and vary in their pathogenic potential. ${ }^{8,18-20}$ Asymptomatic carriage of even virulent strains is the most common manifestation of infection ${ }^{22}$ with only a small, relatively unpredictable minority developing disease. When disease occurs, clinical manifestations vary from transient bacteraemia ${ }^{79}$ through relatively benign and not always easy to diagnose syndromes affecting the joints and skin. ${ }^{80}$ to the more readily recognised meningitis or fulminant meningococcaemia (table III). In a small proportion of cases, post-infection immunemediated complications develop. ${ }^{81}$

The outcome of exposure to the meningococcus depends on a complex and poorly understood interaction between the genetic make-up of the organism, and the genetic background and past experiences of the host, probably modified by environmental - particularly seasonal ${ }^{82}$ - factors and co-existent or antecedent viral infection..$^{83}$ Nevertheless, once bacterial and environmental variables have been taken into account, it is the way in which the host is conditioned to respond either de novo, or as a consequence of prior antigenic stimulation, that determines clinical outcome. Although the organism must invade the mucosal surface to cause disease, little is known of the host factors that influence this process. Attention instead has been focused on systemic defences. 
Table III. Meningococcal disease at Northwick Park Hospital, 1985-1992

\begin{tabular}{lc}
\hline \multicolumn{1}{c}{ Clinical syndrome } & $\begin{array}{c}\text { Number } \\
\text { of cells }\end{array}$ \\
\hline Meningitis & 30 \\
Meningitis + septicaemia & 9 \\
Septicaemia & 17 \\
Fulminant meningococcaemia & 4 \\
Benign meningococcaemia & 3 \\
Fever, polyarthritis acute & 4 \\
Fever, polyarthritis chronic & 3 \\
Septic arthritis & 2 \\
Total & 72 \\
\hline
\end{tabular}

\section{Non-specific host responses}

Normal reticulo-endothelial function is an important facet of protection against meningococcal disease as evidenced by the severe septicaemia seen in the splenectomised patient. ${ }^{84}$ Complement activation plays a complex role. The alternative pathway appears critical, at least in the non-immune host, since properdin deficiency predisposes the fulminant infection. ${ }^{85}$ Terminal complement cascade deficiencies are associated with recurrent neisserial infections. ${ }^{86}$ However, excessive complement activation may have a deleterious effect and is correlated with disease severity. ${ }^{87}$ The way in which the host handles immune complexes may determine whether immunopathological consequences ensue.

Host handling of the LOS shed by meningococci in the form of cell-wall blebs has been little explored, although LOS may be central to disease manifestations. ${ }^{87,88}$ High density lipoproteins readily complex with LOS molecules rendering them less toxic ${ }^{89}$ the acute phase response also involves the generation of LPS binding proteins. ${ }^{90,91}$ The genetic control of these and cytokine responses, particularly generation of tumour necrosis factor (TNF) and interleukin (IL)$6^{92-95}$ may be relevant to both the development of disease and its diversity.

\section{Specific immune responses}

While the potential for variation in the non-specific defence mechanisms is speculative, the presence of, or ability to mount, a relevant antibody response is currently accepted as the major barrier to disease. ${ }^{96}$ Natural immunity develops with age, perhaps in response to relatively avirulent meningococci or other cross-reacting antigens. ${ }^{97,98}$ Therefore, the identification of the antigens involved, determining the function of the antibodies generated, and developing appropriate methods for their testing are crucial to our understanding of the immune response.

\section{Antigens involved in the immune response}

The antigenic repertoire of $N$. meningitidis is summarised in table IV.
Capsular polysaccharides. Both disease and the carrier state induce antibodies to the group-A polysaccharide. ${ }^{99}$ All age groups respond to disease, the majority producing a four-fold increase in antibody levels which may be useful diagnostically, although the strength of the response is age-dependent. A few individuals, irrespective of age, fail to respond, perhaps because of an immunological defect. ${ }^{100}$ Although less well studied, a similar pattern is seen in infection with group-C strains in adults and children over 2 years old. Data on infants is scant but a 4-month-old child failed to develop anticapsular antibody. ${ }^{101} \mathrm{Re}-$ sponses to these polysaccharides are seen very early after admission to hospital $;{ }^{102}$ some individuals have high levels at the time of diagnosis. ${ }^{99}$

Group-B polysaccharide is a poor immunogen, although young adults usually respond with a fourfold or greater increase of predominantly IgM antibody. ${ }^{101,103}$ The response in children is more variable. Griffiss et al. ${ }^{101}$ detected a response in only eight of 26 patients and in these the response was of a significantly lower magnitude than in adults. Anti-polysaccharide responses are probably under genetic control ${ }^{104}$ but neither this nor the potential importance of antibody avidity ${ }^{105}$ has been fully explored.

Sub-capsular antigens. Components of the outer membrane are immunogenic when examined by ELISA with outer-membrane complex as antigen. ${ }^{106,107}$ Low levels of antibody are found usually in the general population and early in disease, but IgM, IgA, IgG and IgG3 antibodies are induced rapidly in all age groups. When examined by this technique, some of these antibodies are cross-reactive across serogroups and sero-subtypes of meningococci, as well as other Neisseria sp. ${ }^{108}$

SDS-PAGE and immunoblotting, ${ }^{109}$ specific antigen purification ${ }^{110,11}$ and competitive antibody assays with MAbs ${ }^{110-112}$ have been developed to attempt to resolve the antigenic specificity of such reactions. Significant host-to-host variation is seen in the responses to class $1,2 / 3$ and 4 proteins and to LOS. Strong responses are usually seen to the class 5 proteins, ${ }^{113}$ which tend to be strain specific, to $\mathrm{H} 8^{114}$ those proteins induced in the outer membrane under conditions of stress, particularly the iron-regulated proteins ${ }^{115,116}$ - and to other minor undefined proteins ${ }^{113}$ many of which show cross reactivity across serogroups and serotypes. ${ }^{113,116}$

\section{Antibody functionality}

While it is evident that the host may respond to a range of meningococcal antigens, it is less clear what function such antibodies effect in vivo. Three possible functions have been described: complement-dependent bacteriolysis; $;{ }^{96}$ complement-dependent/independent opsonisation and phagocytosis; ${ }^{117}$ and cell-mediated antibacterial activity of mononuclear cells. ${ }^{118}$ Their relative importance is currently unknown. 
Table IV. Antigenic repertoire of $N$. meningitidis

$\begin{array}{ll}\begin{array}{l}\text { Capsule } \\ \text { Outer-membrane proteins } \\ \text { (OMPs) }\end{array} & \begin{array}{l}\text { Major classes 1-5 } \\ \text { Iron regulated } \\ \text { Other stress induced } \\ \text { Minor-ill-defined }\end{array} \\ \begin{array}{l}\text { Lipo-oligosaccharides } \\ \text { (LOS) }\end{array} & \\ \text { Pili } & \\ \text { IgA protease } & \end{array}$

Table V. Targets for bactericidal activity

$\begin{array}{ll}\text { Polysaccharides } & \\ \text { MAb-defined epitopes on } & \\ \text { Class 1 } & \text { MOMP } \\ \text { Class 2/3 } & \text { MOMP } \\ \text { Class 5 } & \text { MOMP } \\ \text { 70-kDa iron-induced } & \\ \text { LOS } & \end{array}$

MOMP, major outer-membrane protein.

However, the keynote studies of Goldschneider et al. ${ }^{96}$ which correlated the presence of bactericidal activity in pre-exposure sera with protection, and its absence with susceptibility, coupled with the predisposition of individuals with deficiencies of the terminal complement cascade to neisserial infection, have become accepted as attesting to the pre-eminence of serum bactericidal activity. ${ }^{119}$ Several targets for bactericidal antibody have been defined with mouse MAbs (table V). However, whether the human immune system responds to the same epitopes remains controversial. ${ }^{120}$

Anticapsular $\mathrm{A}$ and $\mathrm{C}$ antibodies are bactericidal and protective. ${ }^{99,101}$ Bactericidal responses to subcapsular antigens are more difficult to evaluate, because the performance of such tests is complicated by the potential variation in expression of cell surface targets. Pili, class 5 proteins and LOS are subject to phase variation. ${ }^{38,121,122}$ Variation in the major OMPs can be seen during the course of infection ${ }^{38}$ and the expression of class 5 and class 1 proteins and LOS can vary depending on the site of isolation in a diseased individual. ${ }^{25,123}$

Specific epitope expression may vary, depending on in-vitro growth conditions. ${ }^{124} \mathrm{New}$ or enhanced expression of outer-membrane antigens may be induced by stress or nutrient limitation. ${ }^{125,126}$ The environment milieu to which meningococci are exposed in vivo is unclear, but the variation between organisms grown in vivo and in vitro has been the subject of recent study. ${ }^{127}$ That meningococci are subjected to iron limitation in vivo is suggested by strong immune responses to ironregulated proteins. ${ }^{115,116}$ This has been confirmed by examination of meningococcal cells obtained directly from CSF. ${ }^{128}$

Variability in cell-surface molecules, both within a single isolate and amongst isolates of the same clone, ${ }^{25}$ or variation in their expression in vivo, may explain the apparent paradox that some patients have positive blood cultures in the presence of serum bactericidal activity, and the observation that serum collected from Gambian children, prior to their developing disease, had significant bactericidal activity against a representative isolate. ${ }^{129}$ An alternative explanation for the apparent disappearance of bactericidal activity involves the induction of $\operatorname{IgA}$ antibodies which block the bactericidal effects of IgG and IgM against polysaccharide $^{130}$ and LOS $;^{119}$ or the generation of antibodies against non-protective targets on the class 4 protein, ${ }^{131}$ which would hinder the accessibility of protective antibody.

Although bactericidal activity has been most studied, it may be neither the only nor the dominant function provided by antibody. Antibodies to group$\mathrm{A}$ and group-C polysaccharides have opsonising activity, ${ }^{132}$ but the latter may be more important in group-B infection. ${ }^{117}$ Opsonic activity is low early in disease, but increases rapidly, ${ }^{133}$ exhibiting a broad range of activity across serogroups and serotypes, suggesting that the relevant targets are unrelated to those epitopes defined by current serotyping schemes. ${ }^{134}$ It remains unclear whether opsonising antibody, which may be detectable at lower concentrations than bactericidal antibody, ${ }^{132}$ could account for the majority of individuals who are exposed to an epidemic strain becoming carriers rather than cases, ${ }^{22}$ or whether this is determined by the speed of their immune response.

\section{Conclusions}

Evaluation of the host responses to meningococcal infection has generated a number of laboratory assays that enable serodiagnosis, particularly in those who present with less common manifestations or when prior therapy precludes a cultural diagnosis. Less impact has been made in defining the relevant target for immunoprotection, particularly in group-B disease, and determining the mechanisms that allow for the high grade bacteraemia, which is the commonest cause of death. These remain important challenges.

THE RELEVANCE OF CLINICAL FEATURES AND PROGNOSTIC INDICATORS IN THE MANAGEMENT OF MENINGOCOCCAL DISEASE

A. P. J. Thompson, Omnia Marzouk, J. A. Sills and C. A. Hart*

Institute of Child Health and *Department of Medical Microbiology, Royal Liverpool Children's Hospital (Alder Hey), Liverpool L12 $2 A P$

\section{Introduction}

The incidence of meningococcal disease in the Mersey Region in 1991 was $4 \cdot 7 / 100000$ population. ${ }^{10}$ This is the highest incidence of any region in England and Wales, but underestimates higher local figures because of variation within the Region, e.g., the incidence around the conurbations of Liverpool and 
Table VI. Clinical presentation of meningococcal disease in 152 consecutive children in the Mersey Region studied prospectively between November 1988 and July 1990

\begin{tabular}{lcc}
\hline \multirow{2}{*}{ Clinical status } & \multicolumn{2}{c}{ Number $(\%)$ of } \\
\cline { 2 - 3 } & survivors & deaths \\
\hline Meningitis & $17(100)$ & $0(0)$ \\
Septicaemia and meningitis & $86(93 \cdot 5)$ & $6(6 \cdot 5)$ \\
Fulminant septicaemia & $36(83 \cdot 7)$ & $7(16 \cdot 3)$ \\
Total & $139(91 \cdot 4)$ & $13(8 \cdot 6)$ \\
\hline
\end{tabular}

Birkenhead in the northern part is much higher than that in rural Cheshire in the south. This high incidence has helped make research into meningococcal disease a priority for the clinicians on Merseyside, who have collaborated in several studies over the last 4 years. Data from these studies are presented here to illustrate the relevance of clinical features and prognostic indicators in the management of meningococcal disease.

\section{Clinical features}

Early recognition of meningococcal disease is essential for its successful treatment. Unfortunately there is still widespread ignorance and confusion about the presenting clinical features of the disease which is hindering early recognition, delaying urgent treatment and hampering education of the general public via the media. Life-threatening meningococcal disease does not present primarily as meningitis. ${ }^{3}$ During the spread of the organism via the blood to the meninges, the inflammatory cascade may be activated, precipitating an acute vasculitic picture which can progress to fullblown septicaemia with shock. Of 152 children studied prospectively between November 1988 and July 1990 in the Mersey Region (table VI), only $11 \%$ (17 children) had meningitis alone, and none of this group died. The remaining $89 \%$ (135 children) presented with clinical evidence of bacteraemia or septicaemia; this was accompanied by meningitis in $61 \%$ (92 children), but fulminant septicaemia was present in $28 \%$ (42 children). Mortality was $9.6 \%$ (13 of 135 ) in the group with a septicaemic component to the illness. Mortality in the group with fulminant septicaemia was $16.3 \%$, which is higher than in the remaining children, though failing to achieve statistical significance, probably because of small numbers.

The clinical features of meningococcal disease in this group are shown in table VII. The main features at presentation were fever $(88.8 \%)$, rash $(68.4 \%)$, vomiting $(67 \cdot 1 \%)$ and drowsiness $(54 \cdot 6 \%)$. Neck stiffness was present in only $50.7 \%$ and other features of meningitis such as coma, headache, irritability and convulsions were present in $\leqslant 30 \%$ of these children. These data emphasise that a petechial and purpuric rash in an ill febrile child is almost pathognomonic of meningococcal disease. A rash was present in 104
$(68.4 \%)$ children at presentation, but evolved after admission in 28 others so that ultimately $132(87 \%)$ children had a rash. Of these, $20(15 \%)$ had a maculopapular rash with no purpuric elements (136), but $112(85 \%)$ had a typical petechial or purpuric rash. This typical petechial or purpuric rash should now be familiar to all doctors who see children in primary and secondary care in the UK, but more difficult to identify early is the maculopapular rash of meningococcal disease, which cannot be differentiated from that of non-specific viral illnesses until petechial or purpuric elements appear. This makes regular reexamination of the ill child with a maculopapular rash an essential part of clinical management.

The relevance of these clinical features becomes clearer still when it is appreciated that many patients are still inappropriately labelled as having "meningitis" when in fact they have features of septicaemia on first contact with primary or secondary care. During outbreaks of meningococcal disease, general practitioners have, in the past, been advised to look for features of "meningitis" and give penicillin if these are found. Although meningococcal septicaemia is now more explicitly included in this advice, many general practitioners have never seen a case, and may not feel that the advice is relevant to them. This may remain so even during a local outbreak because of the tendency of the press to publicise meningococcal septicaemia as "meningitis"!

\section{Doctors, the public and the press}

In a local outbreak of 14 cases of meningococcal disease in South Cheshire, all 14 children had septicaemia, but only six had meningitis. Four died from fulminant septicaemia. Forty-three press cuttings (obtained from the International Press Cutting Bureau) relating to the outbreak all described the disease as "meningitis", only two (4.7\%) mentioned septicaemia. ${ }^{137}$ Advice warning about the features of the disease was given to the public in $26(60 \%)$ of the cuttings. This is compared with the clinical features of the 14 cases in fig. 4. Comparison of the two datasets demonstrates that the media publicised potentially misleading advice, emphasising the presenting features of meningitis, and neglecting the importance of the vasculitic rash. This caused considerable confusion amongst the general public and professionals in primary care. Parents of children subsequently admitted to hospital with meningococcal disease complained that they had been misinformed by the advice, which seriously risked misdirecting vigilance and resources. ${ }^{137}$

Advice given to the press should take into account the clinical features of the cases who have already presented to hospital, confirmation of the organism as the meningococcus, and knowledge of the usual clinical features of meningococcal disease. Clinicians (paediatricians, physicians and intensivists) and Consultants in Communicable Disease Control should 
Table VII. Clinical features of meningococcal disease in 152 children at presentation

\begin{tabular}{lc}
\hline Clinical feature & $\begin{array}{c}\text { Number }(\%) \\
\text { of children }\end{array}$ \\
\hline Fever & $135(88 \cdot 8)$ \\
Rash & $104(68 \cdot 4)$ \\
Vomiting & $102(67 \cdot 1)$ \\
Drowsiness & $83(54 \cdot 6)$ \\
Neck stiffness & $77(50 \cdot 7)$ \\
Coma & $46(30 \cdot 3)$ \\
Hypotension & $38(25 \cdot 0)$ \\
Headaches & $34(22 \cdot 4)$ \\
Irritability & $34(22 \cdot 4)$ \\
Poor feeding & $28(18 \cdot 4)$ \\
Diarrhoea & $17(11 \cdot 2)$ \\
Walking problems & $16(10 \cdot 5)$ \\
Convulsions & $15(9 \cdot 9)$ \\
\hline
\end{tabular}

confer to ensure the accuracy of statements issued to the press. This will help avoid misinforming the profession and the public. The "Meningitis Fact Sheet" prepared by the Meningitis Trust ${ }^{138}$ can act as a useful checklist on which to base publicity and statements to the media, but the importance of the petechial or purpuric rash in the diagnosis of meningococcal disease needs to be highlighted.

\section{Prognostic indicators}

Optimal management of children with meningococcal disease is possible only with prompt identification of the most ill; prognostic indicators and scoring systems have been studied to determine their role in quantifying the severity of illness. Possible benefits of scoring systems include: identification of the patient who warrants admission to intensive care; as entry criteria in trials of new therapies or management; and as mandatory components of protocols for use of expensive new therapies in order to manage health service resources efficiently. A further possible benefit would be the use of a scoring system to withhold treatment, but in view of the imperfect performance of all scores so far proposed this is not a realistic expectation and should be ignored.

Poor prognostic clinical features of meningococcal disease include extreme age, a spreading rash of less than $12 \mathrm{~h}$ duration, shock, hypotension, coma, fits before admission, absence of meningism and hyperventilation. ${ }^{139}$ Poor prognostic laboratory features include a white cell count of $<10 \times 10^{9} / 1$, platelet count of $<100 \times 10^{9} / 1$, ESR $<20 \mathrm{~mm} / \mathrm{h}$, metabolic acidosis with $\mathrm{pH}<7 \cdot 30, \mathrm{CSF}$ white cell count $<(50-100) \times 10^{6} / 1$, and antigenaemia.

Numerous prognostic scoring systems based upon these prognostic indicators have been proposed for use in meningococcal disease: these include several specific to the disease. ${ }^{140-142}$ In practice, laboratory turnaround times for investigation, even if short, limit the usefulness of this group of prognostic indicators in the context of the most seriously ill patients, in whom the disease may evolve very rapidly and even a brief delay in initiating therapy should be avoided, but for whom prognostic information would be the most valuable. Ideally, scoring systems to identify the most seriously ill patients should allow therapeutic intervention to be concentrated on this group.

The Glasgow Meningococcal Septicaemia Prognostic Score (GMSPS; table VIII) was proposed as a clinically based score to facilitate the admission of the most ill children to intensive care. ${ }^{143}$ It has been validated retrospectively, ${ }^{144}$ showing sensitivity and a negative predictive value of $100 \%$, specificity $95 \%$,

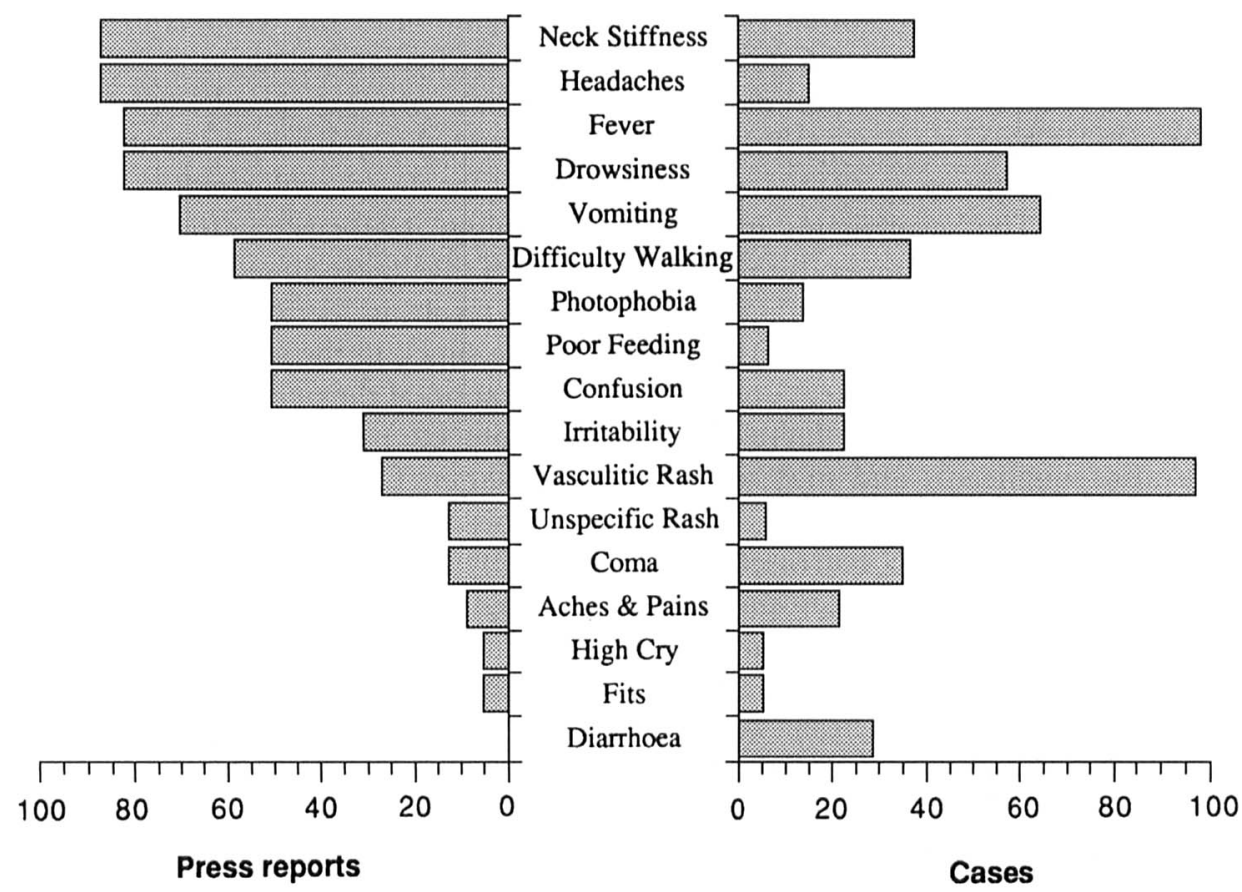

Fig. 4. Comparison of advice to the public on features to watch for published in 26 press reports with clinical details from 14 hospital admissions (both expressed as percentages). 
Table VIII. The Glasgow Meningococcal Septicaemia Prognostic Score (GMSPS) (modified from reference 143)

\begin{tabular}{lc}
\hline Clinical feature & Points \\
\hline BP $<75$ systolic aged $<4$ years & 3 \\
BP $<85$ systolic aged $>4$ years & 3 \\
Skin - rectal temperature difference $>3^{\circ} \mathrm{C}$ & 3 \\
Modified coma scale* score $<8$ & 2 \\
OR deterioration of $\geqslant 3$ points in $1 \mathrm{~h}$ & 2 \\
Deterioration in hour prior to scoring & 1 \\
Absence of meningism & 1 \\
Extending purpuric rash & 15 \\
OR widespread ecchymoses & \\
Base deficit (capillary or arterial) $>8.0$ & \\
Maximum score &
\end{tabular}

* Modified coma scale

(i) Eyes open

spontaneously

to speech

to pain

none

(ii) Best verbal response

orientated

words

vocal sounds

cries

(iii) Best motor response obeys commands

localises pain moves to pain none

Add scores (i) + (ii) + (iii) to give result.

and a positive predictive value $74 \%$ for death at maximum GMSPS of $\geqslant 8$. The GMSPS has been used successfully as an entry criterion in a prospective, randomised double-blind treatment trial of anti-endotoxin therapy with polyvalent immunoglobulin (Pentaglobin) and polymyxin E (colistin). ${ }^{135}$ In this prospective study 109 children had a maximum GMSPS of $\leqslant 7$, and 43 a maximum GMSPS of $\geqslant 8$. There were no deaths in the former group, but 13 deaths in the latter. The GMSPS predicted mortality with sensitivity and negative predictive value $100 \%$, and specificity $78 \%, 83 \%$ and $87 \%$, and positive predictive value $30 \%, 36 \%$ and $42 \%$ at thresholds of 8,9 and 10 respectively. ${ }^{135}$ Maximum GMSPS was achieved within $6 \mathrm{~h}$ of admission in $35(84 \%)$ of 43 children with a score $>7$. The seven items in the GMSPS (hypotension, skin-core temperature difference, coma, acute deterioration, absence of meningism, extending purpura and a gross base deficit) have each been separately validated as components of the score. Other items such as tachypnoea and fluctuating conscious level are also significant, and may allow further refinement of the score. A GMSPS of $\geqslant 8$ in a child with clinical evidence of meningococcal disease is now used in our hospitals to define fulminant meningococcal septicaemia. The GMSPS, via this definition, hence determines admission to intensive care and trials of new treatment. The GMSPS has been widely adopted as an aid to clinical management in district general hospitals on Merseyside. It is also gaining acceptance in areas beyond and will be used to stratify results for analysis in the current prospective study of the anti-endotoxin MAb HA-1A (Centoxin) in menin- gococcal disease. Advantages over other scores are that: it is clinically-based (which avoids delay waiting for laboratory test results); it can be performed equally well by medical or nursing staff after minimal training; it can be repeated to develop information on the change in clinical status; and it does not require specialised equipment or expertise. Theoretical disadvantages of intra- and inter-observer variability have not proved to be a problem in practice, as long as the score is interpreted by an experienced member of the clinical staff. It has been noted that children with high scores on admission may have lower scores after resuscitation. High scores should not justify withholding treatment from the most ill patients.

\section{Effect on management}

Study of clinical features and use of prognostic indicators in clinical management has resulted in better recognition of shock and more aggressive treatment of the critically ill child. Early use of penicillin in primary care, prompt transfer to hospital, and avoidance of lumbar puncture in a clinically unstable child have been general benefits. Volume expansion with plasma to treat shock, rapid progression to inotropic therapy with dobutamine followed by dopamine for nonresponders, invasive monitoring and elective ventilation for the critically ill child with a GMSPS of $\geqslant 8$ have all been confirmed as our standard approach to fulminant meningococcal disease during the last 5 years. There has been a reduction of mortality in fulminant meningococcal septicaemia from $74 \%$ in $1977-1986$ to $30 \%$ in $1988-1990$ concomitant with the introduction of this more aggressive approach.

\section{Conclusions}

Recognition of the features of meningococcal disease, in particular the purpuric rash, is the key to early diagnosis in primary care. Better education of medical staff about the clinical presentation and pathophysiology of the disease will result in more accurate use of terminology, so focusing attention on the septicaemic nature of the illness. In secondary and tertiary care this should result in better management of the gramnegative shock in the severest cases.

Education of the public and the media (newspapers, television, etc.) should be a prime concern of the Consultant in Communicable Disease Control in close liaison with paediatricians and physicians. Education and publicity should avoid prominent use of the term "meningitis" which can misinform, but should emphasise the vasculitic rash.

Scoring systems that can drive certain aspects of clinical management, such as admission to intensive care, are important as entry criteria for treatment trials, and will become mandatory components of protocols for the use of costly new therapies. The GMSPS is currently the most useful scoring system for the practising clinician. 
We thank the Johanne Holly Meningitis Fund, the National Meningitis Trust and Biotest UK for financial support. We are also most grateful to colleagues in paediatrics and other disciplines from Alder Hey, Arrowe Park, Warrington, Countess of Chester, Whiston and St Helen's Hospitals for their contributions.

\section{ChEMOPROPHYLAXIS OF MENINGOCOCCAL DISEASE}

\section{A. Hart and L. E. Cuevas*}

Tropical Microbiology Centre, Department of Medical Microbiology and ${ }^{*}$ Liverpool School of Tropical Medicine, University of Liverpool, PO Box 147, Liverpool L69 $3 B X$

\section{Introduction}

Meningococcal disease is a life-threatening infection and even in survivors may induce lasting debility. It is a communicable disease with a propensity to spread within families and communities. The two main strategies for preventing meningococcal disease are vaccination and chemoprophylaxis. Although capsular polysaccharide vaccines are available for prevention of disease caused by meningococci of groups $\mathrm{A}$ and $\mathrm{C}$ these are not fully efficient in young children ( $<2$ years). ${ }^{145}$ In hyperendemic areas such as Western Europe, group-B meningococci are the major causes of disease and as yet there are no uniformly effective group-B vaccines. ${ }^{146-148}$ This means that, at present, chemoprophylaxis is the only intervention available for prevention of group-B meningococcal disease. Furthermore, the current vaccines do not eliminate nasopharyngeal colonisation ${ }^{\mathbf{1 4 9}}$ and thus do not provide herd immunity.

\section{Rationale}

The pathogenesis of meningococcal disease involves initial colonisation of the nasopharynx followed by translocation to the blood stream. This may result in asymptomatic bacteraemia, fulminant meningococcal septicaemia, meningitis or meningitis with septicaemia. It has been shown that close household contacts of patients with meningococcal disease are themselves at a much higher risk of developing meningococcal disease than the general population. One study from the USA indicated that in the 28-day period following a case there was a $500-800$-fold greater risk to close contacts than for the population in general. ${ }^{150}$ The risk of transmission is greatest in the first week after contact. ${ }^{151,152}$ In a Belgian study, $70 \%$ of secondary household cases occurred in the week following contact, $13 \%$ in the second week, $6 \%$ in the third week and $11 \%$ in the period $21-60$ days after contact. ${ }^{152}$ In a study in the UK, secondary cases were reported after $>33$ weeks following initial contact. ${ }^{153}$ In the Belgian study a relative risk of $>1200$ was found for household contacts in the 60 days following contact. The relative risks for day-care nursery and nursery school contacts were 76 and 23 respectively. ${ }^{152}$ Although young children are at greater risk of acquisition of disease, all age groups are susceptible. Early studies among army recruits in "boot-camps" demonstrated that administration of sulphadiazine eliminated carriage and prevented secondary cases of meningococcal disease. ${ }^{154}$

\section{Strategy}

There are two main strategies employed for preventing secondary cases in household contacts. The first is in effect pre-emptive therapy. This is based on the fact that the majority of secondary cases occur in the first week following contact. Phenoxymethyl-penicillin or amoxycillin is given for 7 days. ${ }^{155}$ This has the advantage that it can be used in pregnant or lactating women. However, penicillin does not eradicate oropharyngeal carriage ${ }^{\mathbf{1 5 6}}$ therefore, the strategy does not remove the risk of secondary cases occurring after the period of treatment. The second strategy is in more widespread use. This involves administration of antibiotics to which the meningococci are susceptible and which are excreted into the oropharyngeal mucosa. The aim of this strategy is to eliminate oropharyngeal carriage, and thereby prevent meningococcal disease.

\section{Antimicrobial agents}

The ideal antimicrobial agent for chemoprophylaxis should be highly active against meningococci, reexcreted into the oropharynx, non-toxic and have minimal effect on the normal flora. The administration regimen should be simple and involve only a short course of therapy.

Although it is stated that many antibiotics, including penicillin, ampicillin, erthyromycin, tetracycline, cephalexin and choramphenicol have failed to eliminate pharyngeal colonisation with meningococ$\mathrm{ci}^{157-159}$ there are few trials demonstrating the degree of failure. For the most part, data come from studying cases of meningococcal disease who were treated with a particular antibiotic which failed to eradicate oropharyngeal carriage. ${ }^{160}$ However, one trial showed that erythromycin failed to eradicate meningococcal carriage in seven out of seven carriers and penicillin $(600000$ units of aqueous procaine penicillin twice daily intramuscularly for 2 days) failed in 61 of 98 carriers. $^{152}$

However, there are several antimicrobial agents for which adequate trial data are available (table IX). Sulphonamides, in particular sulphadiazine, have been used extensively for prophylaxis since World War II, and have proved extremely safe and effective. ${ }^{154}$ Unfortunately, sulphonamide-resistant meningococci are now highly prevalent ${ }^{161,162}$ and sulphonamides should not be used unless it is known that the isolates are sensitive.

Minocycline has been used either alone or in combination with rifampicin ${ }^{\mathbf{1 6 3 , 1 6 4}}$ and has proved highly effective. However, its use should be avoided since it produces an unacceptably high incidence of side effects ${ }^{165}$ and it should not be used in children and pregnant or lactating mothers. 
Table IX. Examples of antimicrobial agents for chemoprophylaxis

\begin{tabular}{|c|c|c|c|c|}
\hline $\begin{array}{l}\text { Antimicrobial } \\
\text { agent }\end{array}$ & $\begin{array}{l}\text { Number } \\
\text { of } \\
\text { carriers } \\
\text { treated }\end{array}$ & $\begin{array}{l}\text { Number } \\
\text { from } \\
\text { whom } \\
\text { carriage } \\
\text { was } \\
\text { eradicated }\end{array}$ & $\begin{array}{c}\text { Efficacy } \\
(\%)\end{array}$ & Reference \\
\hline Penicillin & 118 & 41 & 35 & 156 \\
\hline Erythromycin & 7 & 0 & 0 & 156 \\
\hline Sulphadiazine & 66 & 63 & 95 & 154 \\
\hline \multirow{4}{*}{ Rifampicin } & 48 & 37 & 77 & 169 \\
\hline & 13 & 12 & 92 & 166 \\
\hline & 36 & 27 & 75 & 172 \\
\hline & 64 & 63 & 98 & 167 \\
\hline \multirow[t]{2}{*}{ Ceftriaxone* } & 68 & 66 & 97 & 172 \\
\hline & 37 & 34 & 92 & 167 \\
\hline \multirow{4}{*}{ Ciprofloxacin $\dagger$} & 57 & 51 & 89 & 167 \\
\hline & 336 & 326 & 97 & 173 \\
\hline & 23 & 22 & 96 & 174 \\
\hline & 12 & 11 & 92 & 175 \\
\hline
\end{tabular}

* Single intramuscular dose.

$\dagger$ Single oral dose.

Rifampicin has been in extensive use in recent years and is currently the drug of choice. A 2-day course of rifampicin is effective in eradicating meningococcal throat carriage in $95-98 \%$ of individuals. ${ }^{166,167} \mathrm{Un}$ fortunately, rifampicin-resistant meningococci are emerging ${ }^{168,169}$ and some have even emerged during prophylaxis. ${ }^{170}$ Problems with the use of rifampicin include orange colouration of urine, orange staining of contact lenses and induction of hepatic microsomal enzymes which might render the contraceptive pill ineffective. Long-term therapy with rifampicin is contra-indicated in pregnancy, liver disease and alcoholism. Although it is unlikely that a short course would be harmful, nevertheless there is insufficient evidence to show that it is safe in pregnancy. ${ }^{170} \mathrm{~A}$ further complication arises in countries where tuberculosis is highly prevalent since rifampicin is part of first-line therapy.

The third generation cephalosporin, ceftriaxone, has been found to be highly effective in eradicating throat carriage of meningococci. ${ }^{167,171,172}$ In controlled trials, ceftriaxone has been shown to be $97 \%{ }^{172}$ and $92 \%{ }^{167}$ effective compared with rifampicin at $75 \%{ }^{172}$ and $98 \%,{ }^{167}$ respectively. Ceftriaxone is given as a single intramuscular injection $(250 \mathrm{mg}$ for adults and $125 \mathrm{mg}$ for children under 15 years), and it can be given to young children and pregnant women. Its major disadvantage is the need for an intramuscular injection which may be painful. Among the new fluoroquinolones, ciprofloxacin is effective in eradicating throat carriage of meningococci. In both open $^{173-175}$ and comparative ${ }^{167}$ trials, a single oral dose (500 mg or $750 \mathrm{mg}$ ) of ciprofloxacin has been shown to be $89-97 \%$ effective in eradicating carriage. The benefit of a single dose regimen is that compliance is good and side effects are few. Fluoroquinolones are contra-indicated in pregnancy and they are not licensed for routine use in children because cartilage damage to the weight bearing joints has followed administration to young beagle dogs. However, it is unlikely that a single dose would produce such damage in children and, in a study in children in Malawi, single dose chemoprophylaxis resulted in side effects in $<1 \%$ of those treated and there were no joint problems. ${ }^{167}$

\section{Who should receive prophylaxis?}

This can be a difficult problem. Household contacts are usually defined as those sleeping in the same household and those likely to have exchanged saliva either by kissing or coughing. The incubation period of meningococcal disease is $2-10$ days and the prophylaxis should be given to those who have been household contacts at any time during the incubation period. There is no evidence to suggest that hospital personnel are at a greater risk unless they have given mouth-tomouth resuscitation. A more vexed problem is contacts in schools or nursery schools or play groups. From the Belgian study, the risk to contacts in nurseries was considerably less than for household contacts. Nevertheless, it was 76- and 23-fold greater than the corresponding age groups in the general population for children in day-care nurseries and pre-elementary schools, respectively. ${ }^{152}$ Guidelines have recently been revised to offer chemoprophylaxis to children in contact with a child with meningococcal disease attending the same pre-school nursery or group. ${ }^{176}$ Although transmission of meningococcal disease has been documented in schools, ${ }^{177}$ the degree of risk has not been estimated accurately. Current guidelines suggest that chemoprophylaxis should be considered only in boarding schools (a situation similar to household contacts) or if two or more cases occur within a 6-month period.

There is little evidence that chemoprophylaxis given during an epidemic affects its course. The circulation of meningococci during epidemics is so great that those given chemoprophylaxis may well become recolonised. Finally it must be remembered that the index case may well require chemoprophylaxis, especially if their meningococcal disease is treated with penicillin and chloramphenicol. Also, vaccination of close household contacts is not a substitute for chemoprophylaxis since protective antibody levels will take a minimum of $2-4$ weeks to be achieved and, as described earlier, the risk of transmission is greatest in the first week of contact.

\section{Does it work?}

There is little doubt that appropriate antimicrobial agents eradicate throat carriage of meningococci with success rates of $77-97 \%$ (table IX). Reasons for failure will include poor compliance, inadequate dosage ${ }^{153,178}$ and rapid re-colonisation following acquisition from other colonised individuals. ${ }^{179}$ Since the pathogenesis of meningococcal disease involves initial colonisation 
of the throat, it is assumed that eradication of colonisation prevents disease. There is no formal proof of this for household contacts, indeed cases do arise after rifampicin prophylaxis. ${ }^{153,179}$ In contrast, there is evidence that chemoprophylaxis does prevent disease in military recruits. For example, in one military community, 17 cases of meningococcal meningitis occurred in a group of recruits not given prophylaxis whereas only two cases occurred in a similar group of recruits with the same risk of exposure who were given sulphadiazine prophylaxis. ${ }^{\mathbf{1 5 4}}$

\section{Concluding remarks}

There does seem to be compelling evidence for giving chemoprophylaxis for contacts of cases of meningococcal disease. Several antimicrobial agents have good efficacy, varying degrees of ease of administration and little risk of side effects. However, the use of chemoprophylaxis is cumbersome, elicits anxiety among donors and recipients alike, has only shortterm benefit, and is expensive. ${ }^{180}$ Clearly, since meningococcal disease is an important cause of morbidity and mortality, mass vaccination would be a more useful intervention. This will require the development of new polysaccharide-protein conjugate vaccines for groups $\mathrm{A}$ and $\mathrm{C}$ meningococci and effective vaccine for group-B meningococci.

\section{MENINGOCOCCAL VACCINES}

\section{J. E. Heckels}

Molecular Microbiology Group, University of Southampton Medical School, South Block, Southampton General Hospital SO9 4XY

\section{Introduction}

The major problem in the control of meningococcal disease continues to be the lack of an effective vaccine against $N$. meningitidis. The ideal vaccine would be effective against all strains of meningococci, would induce long-term immunity and would be suitable for incorporation into the normal childhood immunisation programme. The currently available vaccines fall far short of these goals. This review will briefly describe the background to the development of the current vaccines and their limitations, the current status of experimental vaccines and some of the prospects for future developments.

\section{Antigenic structure of the meningococcus}

Following the early work of Heist in the 1920s, it has become largely accepted that natural immunity to meningococcal infection is correlated with presence in individuals of serum bactericidal activity against the meningococcus. ${ }^{181}$ Indeed, Heist provided a tragic demonstration of this thesis himself, lacking bactericidal activity in his own serum he contracted meningococcal meningitis and died before his seminal paper was published. Therefore, since then the de- velopment of meningococcal vaccines has been based on attempts to understand the antigenic structure of the bacteria and in particular to identify those antigens on the surface which are recognised by the antibodies that promote complement-mediated bactericidal killing.

Virtually all isolates from invasive disease produce an extracellular, anti-phagocytic capsule composed of polysaccharide. Meningococci can be divided into a number of serogroups based on antigenic differences between the capsular polysaccharides, with most disease caused by serogroups A, B and C. ${ }^{182}$ Underlying the capsule is the outer membrane which, like that of other gram-negative bacteria, contains LOS and a restricted number of proteins, some of which are responsible for further antigenic differences between strains. The major OMPs have been divided into five structural classes (class 1, 2, 3, 4 and 5 proteins). ${ }^{183}$ All strains possess either a class 2 or class 3 protein as the predominant protein of the outer membrane, expression of the two classes being mutually exclusive. The class $2 / 3$ proteins show antigenic diversity between strains, which forms the basis for differentiation of strains into serotypes; similar differences in the class 1 proteins are responsible for subtype specificity. ${ }^{184}$ The class 4 protein is highly conserved between strains whereas the class 5 proteins are highly heterogeneous, undergoing antigenic shift within a single strain during the course of an infection. ${ }^{38}$

\section{Capsular polysaccharide vaccines}

Pioneering investigations by Gotschlich and colleagues into the basis of immunity showed that much of the bactericidal effect of serum could be ascribed to the presence of antibodies directed against the capsular polysaccharide, demonstrating the potential of these antigens as vaccine agents. ${ }^{97}$ This work led to the purification of the capsular polysaccharides and to their ultimate incorporation into the tetravalent vaccine currently available for immunisation against serogroups A, C, Y and W135. Such vaccines have been used successfully to reduce the high incidence of meningococcal infection among military recruits and to halt the progress of epidemics caused by group-A organisms. ${ }^{185}$

Despite the success of the capsular polysaccharide vaccines in such situations, they have not been able to influence the incidence of much of meningococcal infection. The purified capsules, like other polysaccharide antigens, do not promote an effective Thelper cell response. Consequently, immunological memory is not induced, the protective antibody response is short lived and there is a poor immune response in young children, the age group who are at greatest risk of infection. ${ }^{182}$ Furthermore, the current vaccines provide no protection against the group-B meningococcus, the predominant cause of infection in most temperate countries. The group-B polysaccharide is composed of repeating units of $\mathrm{N}$-acetyl 
neuraminic acid with 2-9 linkages. Structurally and immunologically related molecules have been identified on human cells, particularly in developing fetal brain tissue, and it would appear that the poor immunogenicity of the group-B polysaccharide is due to immunological tolerance. ${ }^{186}$ Indeed, it has been suggested that caution should be exercised in any attempts to break tolerance by immunisation, because of the possibility of inducing auto-immune processes.

\section{Outer-membrane vaccines}

The problems associated with the use of vaccines based on the capsular polysaccharide led to investigation of the use of sub-capsular antigens as immunising agents. The rationale behind such studies was the observation that antibodies directed against outer membrane components promoted complement-mediated bactericidal killing of capsulate strains. Since isolated outer membranes contain LOS with its inherent endotoxic activity, detergent extraction has been used to deplete the LOS. The resulting experimental vaccines consist of membrane vesicles containing a mixture of OMPs. After extensive studies in laboratory animals, such preparations were shown to be both safe and immunogenic in human volunteers and to induce significant increases in bactericidal antibody titres against group-B meningococci. ${ }^{185} \mathrm{Lim}-$ ited field trials confirmed these observations but could not provide sufficient data to confirm protective immunity. However, the promising results led to further large scale trials in some countries with a particularly high incidence of meningococcal disease.

Since 1974, Norway has had the highest incidence of meningococcal disease in northern Europe, with attack rates reaching epidemic proportions. The case-fatality rate was high at about $10 \%$ and a large proportion of cases occurred in teenagers. ${ }^{187}$ The overwhelming majority of the cases were caused by meningococci of serogroup B, type 15 and subtype 7,16. Therefore, a vaccine consisting of LOS-depleted outer-membrane vesicles was prepared from one such isolate. The vaccine was used in a double blind, placebo-controlled trial with 170000 secondary school students that took place during 1988-1991. The participants received two immunisations at an interval of 6 weeks. At the completion of the trial, analysis of the data showed significant protection against group-B meningococcal disease, with a calculated protection rate of $57 \% .{ }^{147}$ However, it was concluded that the overall level of protection was too low to justify full scale public vaccination.

A similar efficacy trial in teenagers has also been performed in Cuba with OMP-based vaccine, although the precise composition of the vaccine has not been revealed. ${ }^{146}$ The observed efficacy rate was $83 \%$ and, as a result, mass immunisation of the population between 3 months and 20 years of age has been carried out. The estimated overall efficacy following mass vaccination was reported to be $93 \%$, and the incidence of meningococcal disease in children under 6 years old showed evidence of a dramatic decline. ${ }^{146}$ However, contrasting results have been obtained after an attempt to use the same vaccine to halt an epidemic of serogroup-B disease in Sao Paulo, Brazil. A casecontrol study showed a considerable variation in estimated vaccine efficacy, which could be related to the age of the immunised group. ${ }^{148}$ Protection was calculated at $74 \%$ for children older than 4 years while no protective effect could be demonstrated in children younger than 2 years of age. Unfortunately the overall incidence of infection in the population aged 1-6 years showed no difference before and after the vaccination campaign. It was concluded that while the vaccine might be effective in preventing epidemic serogroup-B meningococcal disease in older children and adults, its usefulness for control of epidemic disease was questionable.

A somewhat different strategy has been used by Zollinger and colleagues in the development of an OMP-based vaccine used for field trials in Chile. ${ }^{188}$ In contrast to the LOS-depleted vesicles described above, the vaccine contained more highly purified OMPs present as soluble macromolecular aggregates noncovalently complexed with group-C capsular polysaccharide. The vaccine was given in two doses, 6 weeks apart, and induced antibody responses in vaccinees which were bactericidal for group-B meningococci, although antibody levels were found to have declined markedly after 6 months. Nevertheless, subsequent analysis of the incidence of meningococcal infection reported a protective effect of $c .70 \%$ in vaccinees aged 5-21 years, although no significant protection was detected in those aged 1-4 years. ${ }^{189}$

Although the results of the vaccine trials described above show some significant differences, particularly in the reported protective effects, general conclusions can be drawn. Most importantly, it is clearly possible for OMPs to induce a bactericidal response and to produce significant protection against group-B meningococcal disease. However, it would appear that, at least with the vaccination regimens so far used, the protective effect may be of rather limited duration and that effective immunity is not induced in young children. Nevertheless, the results obtained to date are encouraging for the ultimate prospect of the development of OMP-based vaccines effective against group-B meningococci. Further work is clearly needed to address the problems of improving immunogenicity and prolonging the duration of the effective immune response.

\section{Future developments}

Improved outer-membrane vaccines. The partial success of the OMP-based vaccine will clearly stimulate further studies. In addition to improvements to the vaccination regimens, such as the inclusion of a booster immunisation to prolong immunity, improvements to the composition of the vesicles are under 
investigation. One potential problem is that outer membranes from all strains of meningococci contain the highly conserved class 4 protein, which is capable of inducing cross-reacting antibodies which are not only non-bactericidal, but also block the bactericidal effect of antibodies direct against other surface antigens. ${ }^{131}$ Since class 4 negative mutants can be readily derived in the laboratory, it is likely that future OMPbased vaccines will be formulated to exclude this protein. Additional proteins will be included in the membranes by growth of bacteria under conditions, such as iron deprivation, where they produce proteins which may be expressed during infection, but only in limited amounts during normal laboratory growth. ${ }^{\mathbf{1 9 0}}$

One problem posed by the outer-membrane vesicle vaccines is that the protection induced may be serotype and subtype specific, since the proteins with these specificities are the major components of the vaccines. However, it has been claimed that the Cuban vaccine is effective against all types and subtypes tested, although full details are not yet available. ${ }^{146}$ This cross-reactivity may be due to the presence of high-mol. wt proteins, the precise nature of which has not yet been defined.

One obvious strategy to increase the potential spectrum of protection would be to include outer membranes derived from a number of different strains. As an alternative, Poolman et al. have used recombinant DNA technology to replace the highly variable class 5 protein genes with class 1 protein genes from different strains. ${ }^{191}$ The recombinants produced expressed four different subtype specificities and the addition of a number of further subtypes is feasible. Since subtypespecific antibodies are highly protective in model systems, a vesicle vaccine produced from such recombinants would be expected to have protective effects against a wide variety of strains.

Improved capsular vaccines. As discussed above, the problems of the current capsular polysaccharide vaccines in control of group- $\mathrm{A}$ and $-\mathrm{C}$ infections are largely due to the $\mathrm{T}$-cell independent nature of polysaccharide antigens. Similar problems encountered in immunisation against Haemophilus influenzae, type b have now been resolved by the development of conjugate vaccines in which the capsular polysaccharide is coupled to a carrier protein which provides T-helper cell activity. ${ }^{192}$ This ensures an effective IgG response and induction of immunological memory even in young children. Such vaccines have been used in Finland and the USA for some time and have recently been incorporated into the normal childhood immunisation programme in the UK. Similar conjugate vaccines have also been prepared by coupling the meningococcal group-A and -C polysaccharides to carrier proteins such as tetanus toxoid. ${ }^{193,194}$ The conjugates elicit an immune response indicative of their conversion to $T$-dependent antigens. Thus it would appear that the production of considerably more effective vaccines against infections caused by groups $\mathrm{A}$ and $\mathrm{C}$ meningococci is now scientifically feasible. It is to be hoped that vaccine manufacturers will enable this to become a reality in the not too distant future.

Studies on the development of conjugate vaccines have also introduced the possibility of inducing an immune response against the normally non-immunogenic group-B capsule. A B-polysaccharide-tetanus toxoid conjugate has been shown recently, in laboratory animals, to induce antibodies directed against the polysaccharide via a T-dependent immune response. ${ }^{193}$ Such studies open the possibility of using conjugates for human vaccination but raise the question of the desirability of breaking tolerance to a "self" antigen. However, the authors argue that naturally occurring antibodies directed against the group-B capsule can be detected commonly in adults and are acquired via the placenta in neonates, without any neurological consequences.

By use of a similar approach, Jennings et al. have prepared group-B polysaccharide-tetanus toxoid conjugates, in which the $\mathrm{N}$-acetyl groups on the neuraminic acid have been replaced by propyl residues. ${ }^{194}$ They found that the conjugate induced high levels of antibodies in mice, which were bactericidal for groupB organisms. Of particular interest was the observation that the serum contained two distinct populations of antibodies. The first reacted with purified capsular polysaccharide and were non-bactericidal. The second group of antibodies contained the bactericidal activity and appeared to recognise conformational determinants present only on the native capsule and hence not present on human tissue. These observations raise the question of whether, in the future, it may be possible by appropriate manipulation to induce only the bactericidal, meningococcal specific, antibodies and hence avoid the possibility of auto-immune effects.

Currently, however, the possible use of group-B conjugates still faces the dilemma that only immunisation of man will be able to address the remaining concerns over possible adverse effects of breaking tolerance. It appears likely that initial immunogenicity studies will be carried out in adult males. Only then would it be possible to consider immunising females (who may become pregnant) and young children, the ultimate target group.

Subunit based vaccines. One conclusion of the partial success of the experimental OMP-based vaccines is that an improved vaccine must direct the immune response more specifically towards those antigenic determinants that can induce a protective immune response. ${ }^{188}$ It is not clear from the field trials which component(s) of the vaccines are primarily responsible for the observed protective effect but evidence implicates the class 1 and class $2 / 3$ proteins, which are the major components of the vaccines. This would be in accord with laboratory experiments which have shown that MAbs directed against these proteins, particularly the class 1 protein, are the most effective in bactericidal killing and in animal protection experiments. ${ }^{195}$ 
Class 1 protein. The class 1 protein is, therefore, an attractive vaccine candidate in its own right. However, the presence of other components in the current experimental vaccines, combined with the difficulty of purifying a membrane protein while retaining its native form, have prevented more detailed studies with the antigen itself. Therefore, an alternative strategy is to focus on those regions of the protein which induce the protective antibodies and to attempt to direct the immune response specifically at these determinants. Work in our laboratory has led to an understanding of the immunochemical structure of the class 1 protein and to the localisation of these protective epitopes. The class 1 protein genes from a number of different strains have been cloned ${ }^{196}$ and sequenced, resulting in the availability of the amino-acid sequences of the proteins. ${ }^{197}$ This sequence information has been used to construct a model for the organisation of the protein within the outer membrane. ${ }^{198}$ These studies predict that the class 1 protein molecule contains a series of amphipathic $\beta$-sheets which traverse the outer membrane, generating eight surface exposed hydrophilic loops. Despite antigenic differences the proteins are highly conserved with sequence variation being largely confined to loops 1 and 4. Epitope mapping experiments with synthetic peptides reveal that the protective MAbs recognise antigenic determinants at the tips of these loops, which are the longest and, hence, most accessible to the immune system. ${ }^{197,199}$ This detailed knowledge of the structure and immunochemistry of the class 1 protein has permitted studies designed to target the immune response directed to these protective epitopes. ${ }^{200}$ Short peptides have been chemically synthesised to contain the epitope at the top of loop 4, coupled to carrier protein and used for immunisation. Despite inducing a good immune response to the immunising agent the resulting antisera reacted poorly with the native outer membranes and were nonbactericidal. In order to more closely mimic the native conformation of the class 1 molecule a larger peptide corresponding to the whole of the surface exposed loop was synthesised and conformationally restricted by cyclisation. Immunisation with this peptide produced antibodies which appeared to recognise the three dimensional structure of the protein and which promoted complement-mediated bactericidal killing of the homologous meningococcal strain. These data demonstrate the potential of synthetic peptide immunogens for inducing a protective immune response against group-B meningococci.

LOS. Antibodies directed against meningococcal LOS are bactericidal and protect against infection in animal models. ${ }^{201}$ Therefore, LOS would represent a potential vaccine candidate were it not for its endotoxic properties. Since the antigenic and toxic determinants of LOS are distinct, one approach is to purify the antigenic oligosaccharide and to use this for immunisation after coupling to a carrier protein. ${ }^{202} \mathrm{An}$ alternative strategy has become possible with the availability of information on the structures of the molecules associated with different LOS serotypes. Poolman et al. have chemically synthesised small oligosaccharides corresponding to the antigenic domain of one LOS serotype and coupled this to a synthetic peptide containing a T-cell epitope from the class 1 protein. ${ }^{203}$ However, no information is yet available on the immunogenicity of such constructs and on the biological activities of any antibodies produced.

Other OMPs. In addition to the major OMPs, other surface proteins are under investigation as potential vaccine candidates. Amongst these are proteins induced by growth conditions which may more closely resemble those sometimes found during the course of the natural infection, such as iron deprivation. It had been hoped that, because of conserved biological functions, these proteins might show less strain-tostrain variation than the major surface antigens. However, in some cases, subsequent results have shown significant antigenic differences between strains. ${ }^{204,205}$ An additional problem is that some of these proteins may be present at insufficient levels in the outer membrane to provide effective targets for bactericidal killing, and it remains unclear whether antibodies directed against such proteins may protect against infection by interfering with essential, biological functions. Nevertheless, preliminary evidence suggests that it may be possible to produce a bactericidal response to one such protein which shows some degree of antigenic cross-reactivity. ${ }^{206}$ Much work is currently in progress in this area.

\section{Conclusions}

The current vaccines based on capsular polysaccharides are clearly unsatisfactory, since they are not effective in the youngest children, who are most at risk of infection. Recent advances in the use of polysaccharide-conjugate vaccines should lead to much more effective vaccines against group- $A$ and $-C$ disease but the problem of group $B$ remains. Field trials with OMP-derived vaccines are encouraging since they clearly show that it is possible to induce protective immunity against group-B infection. This needs to be improved and may be achieved, at least in part, by modifications to the vaccine formulation or the immunisation regimens, or both. Alternative vaccines based on the individual surface antigens responsible for the observed immunity are under active laboratory investigation. Any fully effective vaccine may ultimately need to combine several approaches. Further work is clearly required but it is possible to be optimistic about the ultimate development of a much more effective vaccine against meningococcal infection.

The work described in this review, which was carried out in Southampton, was supported by the National Meningitis Trust, the Medical Research Council and the WHO programme for vaccine development. UK.

This symposium was funded by an educational grant from Baye 


\section{References}

1. Cuevas LE, Hart CA. Acute bacterial meningitis in Malawi Malawi Med J 1991; 7: 2-6.

2. Haberberger RL, Fox E, Asselin P, Said-Salah Y, Martinez S, Abbatte EA. Is Djibouti too hot and too humid for meningococci? Trans $R$ Soc Trop Med Hyg 1990; 84: 588.

3. Thomson APJ, Hart CA, Sills JA. Meningococcal disease in Liverpool children 1977-1987: mode of presentation. Ped Rev Commun 1990; 5: 109-116.

4. Hitchcock PJ. Unified nomenclature for pathogenic Neisseria species. Clin Microbiol Rev 1989; 2 Suppl: S64-S65.

5. Virji M, Alexandrescu C, Ferguson DJP, Saunders JR, Moxon ER. Variations in the expression of pili, the effect on adherence of Neisseria meningitidis in human epithelial and endothelial cells. Mol Microbiol 1992; 6: 1271-1279.

6. Perry ACF, Hart CA, Nicolson IJ, Heckels JE, Saunders JA. Inter strain homology of pilin gene sequences in Neisseria meningitidis isolates that express markedly different antigenic pilus types. J Gen Microbiol 1987; 133: 1409-1418.

7. Fox AJ, Jones DM, Gray JJ, Caugant DA, Saunders NA. An epidemiologically valuable typing method for Neisseria meningitidis by analysis of restriction fragment length polymorphisms. J Med Microbiol 1991; 34: 265-270.

8. Caugant DA, Froholm LO, Bovre $\mathrm{K}$ et al. Intercontinental spread of a genetically distinctive complex of clones of Neisseria meningitidis causing epidemic disease. Proc Natl Acad Sci USA 1986; 83: 4927-4931.

9. Moore PS. Meningococcal meningitis in sub-Saharan Africa: a model for the epidemic process. Clin Infect Dis 1992; 14: 515-525.

10. Jones DM, Kaczmarski EB. Meningococcal infection in England and Wales: 1991. CDR Rev 1992; 2: R61-R63.

11. Olyhoek T, Crowe BA, Achtman M. Clonal population structure of Neisseria meningitidis serogroup A isolated from epidemics and pandemics between 1915 and 1983. Rev Infect Dis 1987; 9: 665-692.

12. Moore PS, Reeves MW, Schwarz B, Gellin BG, Broome CV. Intercontinental spread of an epidemic group A Neisseria meningitidis strain. Lancet 1989; 2: 260-263.

13. Li X, Hu X, Gao L, Xi W, Ji Y, Hu Z. The clonal population structure and serosubtypes of Neisseria meningitidis serogroup A isolated in China. In : Achtman M, KohlP, Marchal C, Morelli G, Seiler A, Thiesen B (eds) Neisseriae-1990. Berlin, Walter de Gruyter and Co. 1991: 159

14. Wedege E, Caugant DA, Froholm LO, Zollinger WD. Characterization of serogroup A and B strains of Neisseria meningitidis with serotype 4 and 21 monoclonal antibodies and by multilocus enzyme electrophoresis. J Clin Microbiol 1991; 29: 1486-1492.

15. Wang J-F, Caugant DA, Li X et al. Clonal and antigenic analysis of serogroup A Neisseria meningitidis with particular reference to epidemiological features of epidemic meningitis in China. Infect Immun 1992; 60: 5267-5282.

16. Morelli G, Lammel CJ, Pohler J et al. Immunogenicity and variability of epitopes within the IgAl protease from serogroup A Neisseria meningitidis. Mol Microbiol 1993; (in preparation).

17. Suker J, Achtman M, Wang J-F, Feavers IM, Maiden MCJ. The class 1 outer membrane protein (OMP) of serogroup A meningococci: Epidemiological inferences from nucleotide sequence data. In: Proceedings of the Eighth International Pathogenic Neisseria Conference, 1993: in press.

18. Crowe BA, Wall RA, Kusecek B et al. Clonal and variable properties of Neisseria meningitidis isolated from cases and carriers during and after an epidemic in the Gambia, West Africa. J Infect Dis 1989; 159: 686-700.

19. Salih MAM, Danielsson D, Backman A, Caugant DA, Achtman $\mathbf{M}$, Olcen $\mathbf{P}$. Characterization of epidemic and nonepidemic Neisseria meningitidis serogroup A strains from Sudan and Sweden. J Clin Microbiol 1990; 28: 17111719 .

20. Bjorvatn B, Hassan-King M, Greenwood B, Haimanot RT, Fekade D, Sperber G. DNA fingerprinting in the epidemiology of African serogroup A Neisseria meningitidis. Scand J Infect Dis 1992; 24: 323-332.

21. Achtman M, Neibert M, Crowe BA et al. Purification and characterization of eight class 5 outer membrane protein variants from a clone of Neisseria meningitidis serogroup A. J Exp Med 1988; 168: 507-525.
22. Achtman M, Kusecek B, Morelli G et al. A comparison of the variable antigens expressed by clone IV-1 and subgroup III of Neisseria meningitidis serogroup A. J Infect Dis 1992; 65: $53-68$.

23. Meyer TF, van Putten JPM. Genetic mechanisms and biological implications of phase variation in pathogenic Neisseriae. Clin Microbiol Rev 1989; 2 Suppl: S139-S145.

24. Olyhoek AJM, Sarkari J, Bopp M, Morelli G, Achtman M. Cloning and expression in Escherichia coli of $o p c$, the gene for an unusual class 5 outer membrane protein from Neisseria meningitidis. Microb Pathog 1991; 11: 249257.

25. Achtman M, Wall RA, Bopp $\mathbf{M}$ et al. Variation in class 5 protein expression by serogroup A meningococci during a meningitis epidemic. J Infect Dis 1991; 164: 375-382.

26. Aho EL, Dempsey JA, Hobbs MM, Klapper DG, Cannon JG. Characterization of the opa (class 5) gene family of Neisseria meningitidis. Mol Microbiol 1991; 5: 14291437.

27. Sarkari JF, Olyhoek T, Bopp M et al. Class 5 proteins and opa genes in clones IV-1 and III-1 of Neisseria meningitidis serogroup A. In: Achtman M, Kohl P, Marchal C, Morelli G, Seiler A, Theisen B (eds) Neisseriae-1990. Berlin, Walter de Gruyter and Co. 1991: 539.

28. Virji M, Makepeace K, Ferguson DJP, Achtman M, Sarkari J, Moxon ER. Expression of the Opc protein correlates with invasion of epithelial and endothelial cells by Neisseria meningitidis. Mol Microbiol 1992; 6: 2785-2795.

29. Rosenqvist E, Hoiby EA, Wedege E, Kusecek B, Achtman M. The 5c protein of Neisseria meningitidis is highly immunogenic in humans and stimulates bactericidal antibodies. $J$ Infect Dis 1993: in press.

30. de Cossio MEF, Ohlin M, Llano M et al. Human monoclonal antibodies against an epitope on the class $5 \mathrm{c}$ outer membrane protein common to many pathogenic strains of Neisseria meningitidis. J Infect Dis 1992; 166: 1322-1328.

31. Wang J-F, Morelli G, Bopp $\mathbf{M}$ et al. Clonal and antigenic analyses of Neisseria meningitidis bacteria belonging to the ET37 complex isolated from Mali and elsewhere. In: Achtman M, Kohl P, Marchal C, Morelli G, Seiler A, Thiesen B (eds) Neisseriae-1990. Berlin, Walter de Gruyter and Co. 1991: 141.

32. Wang J-F, Caugant DA, Morelli G, Koumare B, Achtman M. Antigenic and epidemiological properties of the ET37 complex of Neisseria meningitidis. J Infect Dis 1993 (in press).

33. Gotschlich EC, Liu T-Y, Artenstein MS. Human immunity to the meningococcus III. Preparation and immunochemical properties of the group A, group B, and group C meningococcal polysaccharides. J Exp Med 1969; 129: 1349-1365.

34. Sparling PF, Cannon JG, So $\mathbf{M}$. Phase and antigenic variation of pili and outer-membrane protein-II of Neisseria gonorrhoeae. J Infect Dis 1986; 153: 196-201.

35. Connell TD, Shaffer D, Cannon JG. Characterization of the repertoire of hypervariable regions in the protein-II (opa) gene family of Neisseria gonorrhoeae. Mol Microbiol 1990; 4: 439-449.

36. Connell TD, Black WJ, Kawula TH et al. Recombination among protein-II genes of Neisseria gonorrhoeae generates new coding sequences and increases structural variability in the protein-II family. Mol Microbiol 1988; 2: 227-236.

37. Stephens DS, Whitney AM, Rothbard J, Schoolnik GK. Pili of Neisseria meningitidis-analysis of structure and investigation of structural and antigenic relationships to gonococcal pili. J Exp Med 1985; 161 : 1539-1553.

38. Tinsley CR, Heckels JE. Variation in the expression of pili and outer-membrane protein by Neisseria meningitidis during the course of meningococcal infection. $J$ Gen Microbiol 1986; 132: 2483-2490.

39. Pinner RW, Spellman PA, Stephens DS. Evidence for functionally distinct pili expressed by Neisseria meningitidis. Infect Immun 1991; 59: 3169-3175.

40. Stephens DS, Krebs JW, McGee ZA. Loss of pili and decreased attachment to human-cells by Neisseria meningitidis and Neisseria gonorrhoeae exposed to subinhibitory concentrations of antibiotics. Infect Immun 1984; 46: 507-513.

41. Stephens S, Zollinger WD, Schoolnik GK. Pathogenesis of Neisseria meningitidis - effect of pili and pilin sub-unit 
antibodies on adherence of meningococci to human-cells. Clin Res 1983; 31: 22-23.

42. Stephens DS, Hoffman LH, McGee ZA. Interaction of Neisseria meningitidis with human nasopharyngeal mucosa - attachment and entry into columnar epithelial-cells. J Infect Dis 1983; 148: 369-376

43. Stephens DS, McGee ZA. Attachment of Neisseria meningitidis to human mucosal surfaces - influence of pili and type of receptor cell. J Infect Dis 1981; 143: 525-532.

44. Virji M, Kayhty H, Ferguson DJP, Alexandrescu C, Heckels JE, Moxon ER. The role of pili in the interactions of pathogenic neisseria with cultured human endothelial-cells. Mol Microbiol 1991; 5: 1831-1841.

45. Meyer TF. Pathogenic neisseriae - a model of bacterial virulence and genetic flexibility. Int J Med Microbiol 1990; 274 : $135-154$.

46. Perry ACF, Nicolson IJ, Saunders JR. Neisseria meningitidis C114 contains silent, truncated pilin genes that are homologous to Neisseria gonorrhoeae pil sequences. $J$ Bacteriol 1988; 170: 1691-1697.

47. Virji M, Heckels JE, Potts WJ, Hart CA, Saunders JR. Identification of epitopes recognized by monoclonal-antibodies SM1 and SM2 which react with all pili of Neisseria gonorrhoeae but which differentiate between 2 structural classes of pili expressed by Neisseria meningitidis and the distribution of their encoding sequences in the genomes of Neisseria spp. J Gen Microbiol 1989; 135: 3239-3251.

48. Potts WJ, Saunders JR. Nucleotide-sequence of the structural gene for class-I pilin from Neisseria meningitidis-homologies with the pilE locus of Neisseria gonorrhoeae. Mol Microbiol 1988; 2: 647-653.

49. Virji M, Heckels JE. Role of anti-pilus antibodies in host defense against gonococcal-infection studied with monoclonal anti-pilus antibodies. Infect Immun 1985; 49: 621628.

50. Virji M, Heckels JE. The role of common and type-specific pilus antigenic domains in adhesion and virulence of gonococci for human epithelial cells. J Gen Microbiol 1984; 130: 1089-1095.

51. Diaz JL, Virji M, Heckels JE. Structural and antigenic differences between 2 types of meningococcal pili. FEMS Microbiol Lett 1984; 21 : 181-184.

52. Virji M, Heckels JE. Antigenic cross-reactivity of neisseria pili-investigations with type-specific and species-specific monoclonal antibodies. $J$ Gen Microbiol 1983; 129: 27612768.

53. Stephens DS, Whitney AM, Schoolnik GK, Zollinger WD. Common epitopes of pilin of Neisseria meningitidis. J Infect Dis 1988; 158: 332-342.

54. Hagblom P, Segal E, Billyard E, So M. Intragenic recombination leads to pilus antigenic variation in Neisseria gonorrhoeae. Nature 1985; 315: 156-158.

55. So M, Billyard E, Deal C et al. Gonococcal pilus-genetics and structure. Curr Top Microbiol Immunol 1985; 118: 13-28.

56. Perry ACF, Nicolson IJ, Saunders JR. Structural-analysis of the pilE region of Neisseria gonorrhoeae P9. Gene 1987; 60: 85-92.

57. Rothbard JB, Schoolnik GK. The primary sequence and antigenic structure of gonococcal pilin-approaches towards a gonococcal vaccine. Adv Exp Med Biol 1985; 185: 247-273.

58. Rothbard JB, Fernandez R, Schoolnik GK. Strain-specific and common epitopes of gonococcal pili. J Exp Med 1984; 160: 208-221.

59. Schoolnik GK, Fernandez R, Tai JY, Rothbard J, Gotschlich EC. Gonococcal pili-primary structure and receptorbinding domain. $J$ Exp Med 1984; 159: 1351-1370.

60. Zak K, Diaz JL, Jackson D, Heckels JE. Antigenic variation during infection with Neisseria gonorrhoeae-detection of antibodies to surface-proteins in sera of patients with gonorrhea. J Infect Dis 1984; 149: 166-174.

61. Virji M, Heckels JE. Location of a blocking epitope on outermembrane protein-III of Neisseria gonorrhoeae by synthetic peptide analysis. J Gen Microbiol 1989; 135: 18951899.

62. Meyer TF, Billyard E, Haas R, Storzbach S, So M. Pilus genes of Neisseria gonorrhoeae-chromosomal organisation and DNA-sequence. Proc Natl Acad Sci USA 1984; 81: 6110-6114.

63. Meyer TF, Mlawer N, So M. Pilus expression in Neisseria gonorrhoeae involves chromosomal rearrangement. Cell 1982; 30: 45-52.

64. Haas R, Veit S, Meyer TF. Silent pilin genes of Neisseria gonorrhoeae MS11 and the occurrence of related hypervariant sequences among other gonococcal isolates. $\mathrm{Mol}$ Microbiol 1992; 6: 197-208.

65. Haas R, Meyer TF. The repertoire of silent pilus genes in Neisseria gonorrhoeae - evidence for gene conversion. Cell 1986; 44: 107-115.

66. Taha MK, So M, Seifert HS, Billyard E, Marchal C. Pilin expression in Neisseria gonorrhoeae is under both positive and negative transcriptional control. EMBO $J$ 1988; 7 : $4367-4378$.

67. Taha MK, Dupuy B, Saurin W, So M, Marchal C. Control of pilus expression in Neisseria gonorrhoeae as an original system in the family of 2-component regulators. $\mathrm{Mol}$ Microbiol 1991; 5: 137-148.

68. Swanson J, Barrera O, Sola J, Boslego J. Expression of outermembrane protein-II by gonococci in experimental gonorrhea. J Exp Med 1988; 168: 2121-2129.

69. Swanson J, Bergstrom S, Robbins K, Barrera O, Corwin D, Koomey JM. Gene conversion involving the pilin structural gene correlates with pilus and reversible pilin. Cell $1986 ; 47: 267-276$.

70. Swanson J, Bergstrom S, Barrera O, Robbins K, Corwin D. Pilus gonococcal variants - evidence for multiple forms of piliation control. $J$ Exp Med 1985; 162: 729-744.

71. Bergstrom S, Robbins K, Koomey JM, Swanson J. Piliation control mechanisms in Neisseria gonorrhoeae. Proc Natl Acad Sci USA 1986; 83: 3890-3894.

72. Manning PA, Kaufmann A, Roll U, Pohlner J, Meyer TF, Haas R. L-pilin variants of Neisseria gonorrhoeae MS11. Mol Microbiol 1991; 5: 917-926.

73. Haas R, Schwarz H, Meyer TF. Release of soluble pilin antigen coupled with gene conversion in Neisseria gonorrhoeae. Proc Natl Acad Sci USA 1987; 84: 9079-9083.

74. Gibbs CP, Reimann BY, Schultz E, Kaufmann A, Haas R, Meyer TF. Reassortment of pilin genes in Neisseria gonorrhoeae occurs by 2 distinct mechanisms. Nature 1989; 338: $651-652$.

75. Hill SA, Morrison SG, Swanson J. The role of direct oligonucleotide repeats in gonococcal pilin gene variation. $\mathrm{Mol}$ Microbiol 1990; 4: 1341-1352.

76. Seifert HS, Ajioka RS, Marchal C, Sparling PF, So M. DNA transformation leads to pilin antigenic variation in Neisseria gonorrhoeae. Nature 1988; 336: 392-395.

77. Swanson J, Morrison S, Barrera O, Hill S. Piliation changes in transformation-defective gonococci. J Exp Med 1990;171 : 2131-2139.

78. Scocca JJ. The role of transformation in the variability of the Neisseria gonorrhoeae cell-surface. Mol Microbiol 1990; 4: 321-327.

79. Taubkin SP. Neisseria meningitidis bacteraemia. Pediatr Infect Dis $1982 ; 1$ : 374.

80. Olcen P, Eeg-Olofsson O, Fryden A et al. Benign meningococcaemia in childhood. Scand J Infect Dis 1978; 10: $107-111$.

81. Greenwood BM, Whittle HC, Bryceson ADM. Allergic complications of meningococcal disease II. Immunological investigations. $B M J 1973 ; 2$ : 737-740.

82. Greenwood BM, Bradley AK, Wall RA. Meningococcal disease and season in sub-Saharan Africa. Lancet 1985; 2: 829830 .

83. Cartwright KAV, Jones DM, Smith AJ et al. Influenza A and meningococcal disease. Lancet $1991 ; 338: 554-557$.

84. Francke EL, Neu HC. Post splenectomy infection. Surg Clin North Am 1981; 61: 135-155.

85. Densen P, Weiler JM, Griffiss JM, Hoffman LG. Familial properdin deficiency and fatal meningococcaemia. $N$ Engl J Med 1987; 316: 922-926.

86. Ross SC, Densen P. Complement deficiency states and infection. Epidemiology, pathogenesis and consequences of neisserial and other infections in an immune deficiency. Medicine $1984 ; 63: 243-273$.

87. Brandtzaeg P, Mollnes TE, Kierulf P. Complement activation and endotoxin levels in systemic meningococcal disease. $J$ Infect Dis 1989; 160: 58-65.

88. Brandtzaeg $\mathrm{P}$, Kierulf $\mathrm{P}$, Gaustad $\mathbf{P}$ et al. Plasma endotoxin as predictor of multiple organ failure and death in systemic meningococcal disease. J Infect Dis 1989; 159: 195-204. 
89. Emancipator K, Csako G, Elin RJ. In vitro inactivation of bacterial endotoxin by human lipoproteins and apolipoproteins. Infect Immun 1992; 60: 596-601.

90. Schumann RR, Leong SR, Flaggs GW et al. Structure and function of lipooligosaccharide binding protein. Science 1990; 249: 1429-1431.

91. Mathison JC, Tobias PS, Wolfson E, Ulevitch RJ. Plasma lipopolysaccharide (LPS)-binding protein. $J$ Immunol 1992; 149: 200-206.

92. Michie HR, Manogue KR, Spriggs DR. Detection of circulating tumour necrosis factor after endotoxin administration. $N$ Engl J Med 1988; 318: 1481-1486.

93. Waage A, Brandtzaeg P, Halstensen A et al. The complex pattern of cytokines in serum from patients with meningococcal septic shock. $J$ Exp Med 1989; 169: 333-338.

94. Molvig J, Baek L, Christensen P et al. Endotoxin-stimulated human monocyte secretion of interleukin 1 , tumour necrosis factor alpha, and prostaglandin $E_{2}$ shows stable interindividual differences. Scand J Immunol 1988; 27: $705-716$.

95. Jacob CJ, Fronek Z, Lewis GD et al. Heritable major histocompatibility complex class II associated differences in production of tumour necrosis factor X: Relevance to genetic predisposition to systemic lupus erythematosus. Proc Natl Acad Sci USA 1990; 87: 1233-1237.

96. Goldschneider I, Gotschlich EC, Artenstein MS. Human immunity to the meningococcus $I$. The role of humoral antibodies. J Exp Med 1969; 129: 1307-1326.

97. Goldschneider I, Gotschlich EC, Artenstein MS. Human immunity to the meningococcus II. Development of natural immunity. J Exp Med 1969; 129: 1327-1348.

98. Gold R, Lepow M. Present status of polysaccharide vaccines in the prevention of meningococcal disease. Adv Paediatr 1976; 23: 71-93.

99. Kayhty H, Jousimies-Somer H, Pettola H, Makela PH. Antibody response to capsular polysaccharides of Group $\mathrm{A}$ and $\mathrm{C}$ Neisseria meningitidis and Haemophilus influenzae type b during bacteraemic disease. J Infect Dis 1981; 143: 32-41.

100. Ambrosino DM, Siber GR, Chilmonczyk BA et al. An immunodeficiency characterised by impaired antibody responses to polysaccharides. $N$ Engl J Med 1987; 316 790-793.

101. Griffiss JM, Brandt BI, Broud DD et al. Immune response in infants and children to disseminated infections with Neisseria meningitidis. $J$ Infect Dis $1984 ; 150$ : 71-79.

102. Hoffman TA, Edwards EA. Group-specific polysaccharide antigen and humoral antibody response in disease due to Neisseria meningitidis. J Infect Dis 1972; 126: 636-644.

103. Artenstein MS, Brandtt BL, Tramont EC et al. Serological studies of meningococcal infection and polysaccharide vaccination. J Infect Dis $1971 ; 124: 277-288$.

104. Siber GR, Schur PH, Aisenberg AC et al. Correlation between serum $\mathrm{IgG}_{2}$ concentrations and the antibody response to bacterial polysaccharide antigens. $N$ Engl $J$ Med 1980; 267: 302-303.

105. Schlesinger Y, Granoff DM. Avidity and bactericidal activity of antibody elicited by different Haemophilus influenzae Type b conjugate vaccines. J Am Med Assoc 1992; 267 : 1489-1494.

106. Harthug S, Rosenqvist E, Hoiby EA et al. Antibody response in Group B meningococcal disease determined by enzymelinked immunosorbent assay with serotype 15 outer membrane antigen. $J$ Clin Microbiol 1986; 24: 947-953.

107. Rosenqvist E, Harthug S, Froholm LO et al. Antibody responses to serogroup B meningococcal outer membrane antigens after vaccination and infection. J Clin Microbiol 1988; 26: 1543-1548.

108. Maeland JA, Wedege E. Serum antibodies to cross-reactive Neisseria outer membrane antigens in healthy persons and patients with meningococcal disease. APMIS 1989 97: $774-780$.

109. Sugasamara RJ. Recognition of serogroup A Neisseria meningitidis serotype antigens by human antisera. Infect Immun 1985; 48: 23-28.

110. Bundell KR, Fox AJ, Guiver M et al. The development of an inhibition enzyme-linked immunosorbent assay to detect total antibody to the P1.16 subtype antigen of Neisseria meningitidis in human sera. Serodiagn Immunother 1987 1: 353-361.

111. Estabrook MM, Mandrell RE, Apicella MA, Griffiss JM
Measurement of the human immune response to meningococcal lipooligosaccharide antigens by using serum to inhibit monoclonal antibody binding to purified lipooligosaccharide. Infect Immun 1990; 58: 2204-2213.

112. Zollinger WD, Mandrell RE. Studies of the human antibody response to specific meningococcal outer membrane proteins of serotype 2 and 15 . Med Trop 1983; 43: 143-147.

113. Poolman JT, Hopman CTP, Zanen HC. Immunogenicity of meningococcal antigens as detected in patient sera. Infect Immun 1983; 40: 398-406.

114. Black JR, Black WJ, Cannon JG. Neisserial antigen H.8 is immunogenic in patients with disseminated gonococcal and meningococcal infections. $J$ Infect $D$ is $1985 ; 151$ : 650-657.

115. Black JR, Dyer DW, Thompson MK, Sparling PF. Human immune response to iron repressible outer membrane proteins of Neisseria meningitidis. Infect Immun 1986; 54: $710-713$.

116. Ala'Aldeen DA, Wall RA, Borriello SP. Immunogenicity and cross reactivity of the $70-\mathrm{Kda}$ iron regulated protein of Neisseria meningitidis in man and animals. J Med Microbiol 1990; 32: 275-281.

117. Ross SC, Rosenthal PJ, Berberich HM, Densen P. Killing of Neisseria meningitidis by human neutrophils: Implications for normal and complement-deficient individuals. $J$ Infect Dis 1987; 155: 1266-1275.

118. Lowell GH, Smith LF, Artenstein MS et al. Antibody dependent cell mediated antibacterial activity of human mononuclear cells. 1. K-Lymphocytes and monocytes are effective against meningococci in co-operation with human immune sera. J Exp Med 1979; 150: 127-137.

119. Griffiss JM. Epidemic meningococcal disease: Synthesis of a hypothetical immunoepidemiologic model. Rev Infect Dis $1982 ; 4: 159-172$.

120. Orren A, Warren RE, Potter PC et al. Antibodies to Meningococcal class 1 outer membrane proteins in South African complement-deficient and complement-sufficient subjects. Infect Immun 1992; 60: 4510-4516.

121. Poolman JT, Hopman CTP, Zanen HC. Colony variants of Neisseria meningitidis strains 2996 (B:2b:P1-2): influence of class 5 outer membrane proteins and lipopolysaccharides. J Med Microbiol 1985; 19: 203-210.

122. Karrula TH, Aho EL, Barritt DS et al. Reversible phase variation of expression of Neisseria meningitidis class 5 outer membrane proteins and their relationship to gonococcal proteins II. Infect Immun 1988; 56: 380-386.

123. Poolman JT, de Marie S, Zanen HC. Variability of low molecular-weight heat modifiable outer membrane proteins of Neisseria meningitidis. Infect Immun 1980; 30: 642-648.

124. Poolman JT, Timmermans HAM, Hopman CTP et al. Comparison of meningococcal outer membrane protein vaccines solubilised with detergent or $\mathrm{C}$ polysaccharide. In: Gonococci and meningococci. Proceedings of 5th International Pathogenic Neisseriae Conference. Dordrecht, Kluver Academic Publishers. 1988: 159-165.

125. van Putten JPM, Linders MTJ, Weel JFL, Poolman JT. Differential expression of Fe-repressible and growth rate sensitive proteins in Neisseria meningitidis and Neisseria gonorrhoeae. In: Gonococci and meningococci. Proceedings of 5th International Pathogenic Neisseriae Conference. Dordrecht, Kluver Academic Publishers. 1988: 781-788.

126. Keevil CW, Major NC, Davies DB, Robinson A. Physiology and virulence determinants of Neisseria gonorrhoeae grown in glucose, oxygen or cystine-limited continuous culture. J Gen Microbiol 1986; 132 : 3289-3302.

127. Wall RA, Davies HA, Borriello SP. Epitopes of serogroup B Neisseria meningitidis analysed in vitro and directly from cerebrospinal fluid. FEMS Microbiol Lett 1989; 65: 129-136.

128. Ala'Aldeen DA, Powell NBL, Wall RA, Borriello SP. Localisation of meningococcal receptors for human transferrin. Infect Immun 1993: in press.

129. Greenwood BM, Greenwood AM, Bradley AK et al. Factors influencing susceptibility to meningococcal disease during an epidemic in The Gambia, West Africa. $J$ Infect 1987; 14: $167-184$

130. Griffiss JM, Bertram MA. Immunoepidemiology of menin- 
gococcal disease in military recruits--II. Blocking of serum bactericidal activity by circulating IgA early in the course of invasive disease. J Infect Dis 1977; 136: 733-739.

131. Munkley A, Tinsley CR, Virji M, Heckels JE. Blocking of bactericidal killing of Neisseria meningitidis by antibodies directed against class 4 outer membrane protein. Microb Pathog 1991; 11: 447-452.

132. Roberts RB. The relationship between group A and group C meningococcal polysaccharides and serum opsonins in man. J Exp Med 1970; 131: 499-513.

133. Halstensen A, Sjursen H, Vollset SE et al. Serum opsonins to serogroup B meningococci in meningococcal disease. Scand J Infect Dis 1989; 21 : 267-276.

134. Guttormsen HK, Bjerknes R, Naess A et al. Cross-reacting serum opsonins in patients with meningococcal disease. Infect Immun 1992; 60: 2777-2783.

135. Marzouk O, Thomason APJ, Sill JA, Hart CA. Clinical features and management of meningococcal disease. Care Crit Ill 1991 ; 7 : 186-187.

136. Marzouk O, Thomson APJ, Sills JA, Hart CA. Features and outcome in meningococcal disease presenting with maculopapular rash. Arch Dis Child 1991; 66: 485-487.

137. Thomson APJ, Hayhurst G. Septicaemia not meningitis: press publicity and meningococcal disease in South Cheshire. Paediatr Rev Commun 1992; 6: 191.

138. Meningitis Fact Sheet. The National Meningitis Trust, Fern House, Bath Road, Stroud, Gloucs. GL5 3TJ. September 1990.

139. Leclerc F, Beuscart R, Guillois B et al. Prognostic factors of severe infectious purpura in children. Intensive Care Med 1985; 11: 140-143.

140. Gedde-Dahl TW, Bjark P, Hoiby EA, Host JH, Bruun JN. Severity of meningococcal disease: assessment by factors and scores and implications for patient management. Rev Infect Dis 1990; 12: 973-992.

141. Leclerc F, Chenand M, Delepoulle F, Diependaele JF, Martinot A, Hue V. Prognostic value of C-reactive protein level in severe infectious purpura: a comparison with eight other scores. Crit Care Med 1991; 19: 430-432.

142. Stokland T, Flaegstad T, Gutteberg TJ. A clinical score for the prediction of outcome of patients with meningococcal infection. Acta Paediatr Scand 1985; 322: S12.

143. Sinclair JF, Skeoch $\mathrm{CH}$, Hallworth D. Prognosis of meningococcal septicaemia. Lancet 1987; 2: 38.

144. Thomson APJ, Sills JA, Hart CA. Validation of the Glasgow Meningococcal Septicaemia Prognostic Score: a 10-year retrospective survey. Crit Care Med 1991; 19: 26-30.

145. Reingold AC, Broome CV, Hightower AW et al. Age-specific differences in duration of clinical protection after vaccination with meningococcal polysaccharide A vaccine. Lancet 1985; 2: 114-118.

146. Sierra GVG, Campa HC, Varacel NM et al. Vaccine against group B Neisseria meningitidis: protection trial and mass vaccination results in Cuba. NIPH Ann 1991; 14: 195210.

147. Bjune G, Hoiby EA, Gronnesby JK et al. Effect of outer membrane vesicle vaccine against group B meningococcal disease in Norway. Lancet 1991; 338: 1093-1096.

148. de Moraes JC, Perkins BA, Camargo MCC et al. Protective efficacy of a serogroup B meningococcal vaccine in Sao Paulo, Brazil. Lancet 1992; 340: 1074-1078

149. Blakebrough IS, Greenwood BM, Whittle HC, Bradley AK, Gilles HM. Failure of meningococcal vaccination to stop transmission of meningococci in Nigerian schoolboys. Ann Trop Med Parasitol 1983; 77: 175-178.

150. The Meningococcal Disease Surveillance Group. Analysis of endemic meningococcal disease by serogroup and evaluation of chemoprophylaxis. J Infect Dis 1976; 134: 201-204.

151. Munford RS, Tauney A de E, Morais JS, Fraser DW, Feldman RA. Spread of meningococcal infection within households. Lancet 1974; 1: 1275-1278.

152. De Wals $\mathrm{P}$, Hertoghe L, Borlee-Grimee I et al. Meningococcal disease in Belgium, secondary attack rate among household, day-care nursery and pre-elementary school contacts. J Infect 1981; 3 Suppl 1: 53-61.

153. Cooke RPD, Riordan T, Jones DM, Painter MJ. Secondary cases of meningococcal infection among close family and household contacts in England and Wales, 1984-7. BMJ 1989; 298: 555-558.
154. Kuhns DW, Nelson CT, Feldman HA, Kuhns LR. The prophylactic value of sulfadiazine in the control of meningococcic meningitis. $J$ Am Med Assoc 1943; 123 : 335-339.

155. Hoiby EA, Moe PJ, Lystad A, Froholm O, Borre K. Phenoxymethyl-penicillin treatment of household contacts of meningococcal disease patients. Antonie van Leeuwenhoek J Microbiol 1986; 52: 255-257.

156. Artenstein MS, Lamson TH, Evans JR. Attempted prophylaxis against meningococcal infection using intramuscular penicillin. Milit Med 1967; 132: 1009-1011.

157. Shapiro ED. Prophylaxis for bacterial meningitis. Med Clin North Am 1985; 69 : 269-280.

158. Wilson HD. Prophylaxis in bacterial meningitis. Arch Dis Child 1981; 56: 817-819.

159. Sanders E, Deal WB. Prevention of meningococcal infections. $J$ Infect Dis $1970 ; 121: 449-451$.

160. Khuri-Bules N. Meningococcal meningitis following rifampicin prophylaxis. Am J Dis Child 1973; 126: 689-691.

161. Burian V, Fofona Y, Sow O. Etude des Neisseria meningitidis isolates en Republique du Mali en 1970. Bull World Health Organ 1974; 51: 495-500.

162. Njoku-Obu AN, Agbo JAC. Meningococcal carrier rates in parts of Eastern Nigeria. Bull World Health Organ 1976; 54: $271-273$.

163. Guttler RB, Counts GW, Avent CK, Beaty HN. Effect on rifampicin and minocycline on meningococcal carrier rates. J Infect Dis 1971; 124: 199-205.

164. Munford RS, Sussurama ZJ, Phillips CJ et al. Eradication of carriage of Neisseria meningitidis in families: a study from Brazil. J Infect Dis 1974; 129: 644-649.

165. Drew TM, Altman R, Black K, Goldfield M. Minocycline for prophylaxis of infection with Neisseria meningitidis: high rate of side effects in recipients. J Infect Dis 1976; 133: 194-198.

166. Kaiser AB, Hennekens CH, Saslow MS et al. Seroepidemiology and chemoprophylaxis of disease due to sulphonamide-resistant Neisseria meningitidis in a civilian population. $J$ Infect Dis $1974 ; 130$ : 217-224.

167. Hart CA, Cuevas LE, Kazembe P, Mughogho GK, Tillotson GS. The use of ciprofloxacin to eradicate oropharyngeal carriage of Neisseria meningitidis: A preliminary analysis. Adv Antimicrob Antineopl Chemother 1992; 11: 167-171.

168. Schubiger G, Munzin J, Dudli C, Wipfli U. Meningokokkenepidemic in einer internatsschule Sekundererkrangkung mit Rifampicin-resistentem Erreger unter Chemoprophylaxe. Schweiz Med Wochenschr 1986; 116: 1172-1175.

169. Blakebrough IS, Gilles HM. The effect of rifampicin on meningococcal carriage in family contacts in northern Nigeria. J Infect 1980; 2: 137-143.

170. Steen JSM, Stainton-Ellis DM. Rifampicin in pregnancy. Lancet $1977 ; 1$ : 604-605.

171. Judson FN, Ehret JM. Single dose ceftriaxone to eradicate pharyngeal Neisseria meningitidis. Lancet 1984; 2 : 1462 1463.

172. Schwartz B, Al-Tobaiqi A, Al-Ruwais A et al. Comparative efficacy of ceftriaxone and rifampicin in eradicating pharyngeal carriage of Group A Neisseria meningitidis. Lancet $1988 ; 1$ : 1239-1242.

173. Gaunt PN, Lambert BE. Single dose ciprofloxacin for the eradication of pharyngeal carriage of Neisseria meningitidis. J Antimicrob Chemother 1988; 21: 489-496.

174. Dworzack DL, Sanders CC, Horowitz EA et al. Evaluation of single-dose ciprofloxacin in the eradication of Neisseria meningitidis from nasopharyngeal carriers. Antimicrob Agents Chemother 1988; 32: 1740-1741.

175. Pugsley MP, Dworzack DL, Roccaforte JS et al. An open study of the efficacy of a single dose of ciprofloxacin in eliminating the chronic nasopharyngeal carriage of Neisseria meningitidis. $J$ Infect Dis 1988; 157: 852-853.

176. PHLS Meningococcal Infections Working Group. Sporadic cases of meningococcal disease in schools. CDR Weekly 1992; 2 (46): 209

177. Hudson PJ, Vogt RL, Heun EM et al. Evidence for school transmission of Neisseria meningitidis during a Vermont outbreak. Pediatr Infect Dis 1986; 5: 213-217.

178. Maher D. A problem with oral rifampicin in the prophylaxis of meningococcal infection. $J$ Infect 1990; 22 : 98-99.

179. Stuart JM, Cartwright KAV, Robinson PM, Noah ND. Does eradication of meningococcal carriage in household con- 
tacts prevent secondary cases of meningococcal disease? BMJ 1989; 298 : 569-570.

180. Cuevas LE, Hart CA. Chemoprophylaxis of bacterial meningitis. J Antimicrob Chemother 1993; 31 Suppl B: 79-91.

181. Heist GD, Solis-Cohen S, Solis-Cohen M. A study of the virulence for man and of human susceptibility to meningococcal infection. 1922; $7: 1-33$.

182. Frasch CE. Vaccines for the prevention of meningococcal disease. Clin Microbiol Rev 1989; 2: S134-S138.

183. Tsai CM, Frasch CE, Mocca LF. 5 structural classes of major outer-membrane proteins in Neisseria meningitidis. $J$ Bacteriol 1981 ; 146: 69-78.

184. Frasch CE, Zollinger WD, Poolman JT. Serotype antigens of Neisseria meningitidis and a proposed scheme for designation of serotypes. Rev Infect Dis 1985; 7: 504-510.

185. Frasch CE. Immunisation against Neisseria meningitidis. In: Easmon CSF, Jeljaszewicz J (eds) Medical microbiology. London, Academic Press: 115.

186. Finne K, Leinonen M, Makela PH. Antigenic similarities between brain components and bacteria causing meningitis. Lancet $1983 ; 2$ : 355-357.

187. Lystad A, Aasen S. The epidemiology of meningococcal disease in Norway 1975-1991. NIPH Ann 1991; 14: $57-66$.

188. Zollinger W, Boslego J, Moran E et al. Meningococcal serogroup B vaccine: protection trial and follow-up studies in Chile. NIPH Ann 1991; 14: 211-213.

189. Zollinger W, Boslego J, Moran EE, Brandt BL, Cruz C, Martinez M. Effect of vaccination with meningococcal OMP vaccine on subsequent antibody response to natural infections. Proceedings of the Eighth International Pathogenic Neisseria Conference. Conde-Glez GM et al. (eds), in press.

190. Banerjee-Bhatnagar N, Frasch CE. Expression of Neisseria meningitidis iron-regulated outer-membrane proteins, including a 70-kilodalton transferrin receptor, and their potential for use as vaccines. Infect Immun 1990; 58: 2875-2881.

191. van der Ley P, Poolman JT. Construction of a multivalent meningococcal vaccine strain based on the class- 1 outermembrane protein. Infect Immun 1992; 60: 3156-3161.

192. Moxon ER, Rappuoli R. Haemophilus influenzae infections and whooping cough. Lancet $1990 ; 335$ : 1324-1329.

193. Devi SJN, Robbins JB, Schneerson S. Antibodies to poly[(2-]8)-alpha-n-acetylneuraminic acid] and poly [(2-]9)-alpha-n-acetylneuraminic acid] are elicited by immunization of mice with Escherichia coli $\mathbf{k} 92$ conjugates: potential vaccines for group-B and group-C meningococci and Escherichia coli k1. Proc Natl Acad Sci USA 1991; 88: 7175-7179.

194. Jennings HJ. Capsular polysaccharides as vaccine candidates. Curr Top Microbiol Immunol 1990; 150: 97-127.
195. Saukkonen K, Leinonen M, Abdillahi H, Poolman JT. Comparative evaluation of potential components for group-B meningococcal vaccine by passive protection in the infant rat and in vitro bactericidal assay. Vaccine 1989; 7: 325-328.

196. Barlow AK, Heckels JE, Clarke IN. Molecular-cloning and expression of Neisseria meningitidis class-1 outer-membrane protein in Escherichia coli k-12. Infect Immun 1987; 55: $2734-2740$

197. McGuinness BT, Clarke IN, Lambden PR et al. Point mutation in meningococcal por-a gene associated with increased endemic disease. Lancet 1991; 337: 514-517.

198. van der Ley $\mathbf{P}$, Heckels JE, Virji M, Hoogerhout P, Poolman JT. Topology of outer-membrane porins of pathogenic Neisseria spp. Infect Immun 1991; 59: 2963-2971.

199. McGuinness BT, Lambden PR, Heckels JE. Class 1 outer membrane protein of Neisseria meningitidis: Epitope analysis of the antigenic diversity between strains, implications for subtype definition and molecular epidemiology. Mol Microbiol 1993: in press.

200. Christodoulides M, McGuinness BT, Heckels JE. Immunisation with synthetic peptides containing epitopes of the class 1 outer membrane protein of Neisseria meningitidis: production of bactericidal antibodies on immunisation with a cyclic peptide. 1992 (unpublished observations).

201. Saukkonen K, Leinonen M, Kayhty H, Abdillahi H, Poolman JT. Monoclonal-antibodies to the rough lipopolysaccharide of Neisseria meningitidis protect infant rats from meningococcal infection. J Infect Dis 1988; 158: 209-212.

202. Verheul AFM, Boons GJPH, Vandermarel GA et al. Minimal oligosaccharide structures required for induction of immune-responses against meningococcal immunotype 11 , 12 , and 13, 7,9 lipopolysaccharides determined by using synthetic oligosaccharide-protein conjugates. Infect Immun 1991; 59: 3566-3573.

203. Boons GJPH, Hoogerhout P, Poolman JT, Van der Marel GA, Van Boom JH. Preparation of a well-defined sugarpeptide conjugate - a possible approach to a synthetic vaccine against Neisseria meningitidis. Bioorg Medic Chem Lett 1991; 1 : 303-308.

204. Pettersson A, Kuipers B, Pelzer $M$ et al. Monoclonalantibodies against the 70-kilodalton iron-regulation protein of Neisseria meningitidis are bactericidal and strain specific. Infect Immun 1990; 58: 3036-3041.

205. Griffiths E, Stevenson P, Ray A. Antigenic and molecular heterogeneity of the transferrin-binding protein of Neisseria meningitidis. FEMS Microbiol Lett 1990; 69: 31-36.

206. Rokbi B, Mazarin V, Maitre G, Dupuy M, Quentin-Millet MJ. Molecular mass heterogeneity, antigenic and genomic variability of transferrin binding proteins among Neisseria meningitidis strains. In: Proceedings of the Eighth International Pathogenic Neisseria Conference. Conde-Glez GM et al. (eds), in press. 